\title{
Flow Configurations of Membraneless Microfluidic Fuel Cells: A Review
}

\author{
Muhammad Tanveer and Kwang-Yong Kim * D
}

Citation: Tanveer, M.; Kim, K.-Y.

Flow Configurations of Membraneless Microfluidic Fuel Cells: A Review. Energies 2021, 14, 3381. https://doi.org/10.3390/ en14123381

Academic Editor: Attilio Converti

Received: 2 May 2021

Accepted: 3 June 2021

Published: 8 June 2021

Publisher's Note: MDPI stays neutral with regard to jurisdictional claims in published maps and institutional affiliations.

Copyright: (c) 2021 by the authors. Licensee MDPI, Basel, Switzerland. This article is an open access article distributed under the terms and conditions of the Creative Commons Attribution (CC BY) license (https:/ / creativecommons.org/licenses/by/ $4.0 /)$.
Department of Mechanical Engineering, Inha University, 100 Inha-ro, Michuhol-gu, Incheon 22212, Korea; tanvir.ranjha@gmail.com

* Correspondence: kykim@inha.ac.kr; Tel.: +82-32-872-3096
Abstract: Membraneless microfluidic fuel cells (MMFCs) are being studied extensively as an alternative to batteries and conventional membrane fuel cells because of their simple functioning and lower manufacturing cost. MMFCs use the laminar flow of reactant species (fuel and oxidant) to eliminate the electrolyte membrane, which has conventionally been used to isolate anodic and cathodic half-cell reactions. This review article summarizes the MMFCs with six major categories of flow configurations that have been reported from 2002 to 2020. The discussion highlights the critical factors that affect and limit the performance of MMFCs. Since MMFCs are diffusion-limited, most of this review focuses on how different flow configurations act to reduce or modify diffusive mixing and depletion zones to enhance the power density output. Research opportunities are also pointed out, and the challenges in MMFCs are suggested to improve cell performance and make them practical in the near future.

Keywords: membraneless microfluidic fuel cell; co-laminar flow; counter flow; radial flow; lateral flow; orthogonal flow; mass-transport losses

\section{Introduction}

There is a strong need for high-performance low-cost power sources to meet the energy demands of electronic devices ranging from the micro scale to the macro scale. Lithium batteries have served the purpose of energy supply for applications that require economical and efficient storage of energy so far [1]. Some advanced batteries such as zincbromine, hydrogen bromine flow, and vanadium redox batteries have been developed [2,3], which introduce innovative concepts such as integrating organic electrolytes to produce higher voltage stability and utilization of semisolid reactants for higher energy density $[4,5]$. However, Kurtzweil [6] and Dyer [7] found that fuel cells are capable of providing energy density of around $4000-7000 \mathrm{Whl}^{-1}$, whereas that of lithium batteries is only around $650 \mathrm{Whl}^{-1}$. Furthermore, fuel cells are more reliable and have a longer life time than batteries [8].

Numerous fuel cells are being developed due to their higher energy density [7,9]. Fuel cells are promising energy-conversion devices addressing the energy crisis in all scales ranging from miniaturized power supplies to larger-scale power plants. Miniaturization of fuel cells increases the surface-to-volume ratio to carry out the reaction swiftly and enhance fuel utilization. Thus, the current and power densities are improved, and the improvement in performance is inversely related to the characteristic channel length. As electrochemical reactions are primarily surface-based, the performance of the fuel cells tend to benefit from miniaturization. Miniaturizing fuel cells also enables cell stacking to produce a large amount energy [10]. Developments in the miniaturization of power sources have led to a new class of power-generating devices [11].

Miniaturized fuel cells or micro fuel cells (MFCs) primarily use a proton exchange membrane (PEM) to conduct protons. MFCs are energy sources for various portable electronic and MEMS devices [12]. An advantage of MFCs is their long-lasting performance 
as a power source. However, there are major issues and challenges to solve. For example, there are key problems in current designs related to the PEM. To ensure higher proton conductivity, cyclic humidification and cooling are required to avoid shrinkage, swelling, and degradation of the PEM, which add complexity to MFC systems. Additionally, fuel crossover through the PEM degrades the cell performance. To fix these problems, novel micro-scale fuel cell designs have been developed [13].

Laminar flows allow the streams of different species to travel in a microchannel without actively mixing. Diffusive mixing between two adjacent streams results in limited development of a mixing region. Membraneless microfluidic fuel cells (MMFCs) were developed by exploiting the properties of meticulous microfluidic interface [13]. MMFCs are a new type of fuel cell that are distinct from other mainstream fuel cells, i.e., proton exchange membrane fuel cells (PEMFCs) [14], molten carbonate fuel cells, direct methanol fuel cells (DMFCs), alkaline fuel cells (AFCs), and solid oxide fuel cells (SOFCs). MMFCs are micro-fabricated devices that produce electrical power via electrochemical reactions involving an oxidant and a fuel, and their delivery and removal are integrated in a single microchannel. Since their first appearance [13,15], MMFCs have attracted attention for their working concept, ease of miniaturization, and utility as a power source for portable devices [16-20]. MMFCs use parallel co-laminar flows of oxidant and fuel to avoid complete mixing [21]. The interface of the oxidant and fuel streams acts as pseudo-membrane and allows the conduction of ions, whereas conventional fuel cells use a membrane for ion exchange [22].

Since the fuel and oxidant flows in MMFCs are laminar with a low Reynolds number, slow diffusion occurs at the fuel-oxidant interface without aggressive convection, which leads to a limited diffusive mixing zone at the center of the microchannel. The elimination of the membrane leads to various benefits compared to conventional membrane fuel cells. Membrane degradation is no longer a concern, and there is no excessive fuel crossover with degradation of the membrane. Furthermore, humidification and cooling are not required, and the choice of fuels and oxidants is flexible. MMFCs can also be made smaller and more compact [14,23-27]. However, the economic aspects are the most prominent advantage. MMFCs can be mass-produced using conventional low-cost methods for microfabrication and micromachining, and the membrane cost is eliminated as well. Furthermore, an MMFC functions efficiently at room temperature.

Previous reviews of MMFCs focused mainly on the architecture, fundamental nature, and performance. Kjeang et al. [24] summarized the developments in various types of MMFCs and briefly explained architectures, fabrication techniques, and types of fuels and oxidants. Tanveer et al. [28] discussed the mass-transport and its impact on the performance of MMFCs. They summarized the computational modeling techniques, future challenges, and opportunities.

Shaegh et al. [17] reviewed electrode architectures and their impacts on the performance of MMFCs. They briefly explained the losses involved in different types of electrode design, such as flow-over, flow-through, and air-breathing designs, as well as the power density and fuel utilization. Goulet et al. [21] described the trends in research on MMFCs and found that further improvements in performance be achieved. They also provided recommendations for future research. Hannapi et al. [29] presented an overview of the system design for different microchannel shapes and the resulting performance of MMFCs. They briefly summarized the working principles, microchannel and electrode architectures, fabrication methods, types of catalysts, and performance of MMFCs.

However, substantial development is still required to solve the problems of lower volumetric power density and insufficient utilization of reactants, which are two fundamental setbacks for the pervasive use of MMFCs. Mass-transport and ohmic losses are key issues that decide the performance of an MMFC. Fuel utilization and volumetric power density can be improved if the mass-transport and ohmic losses are decreased. To accomplish this, various flow configurations with different electrodes and arrangements have been studied. 
Improving the fuel utilization improves the mass-transport, and vice versa, resulting in higher power output (current and power densities).

The mass-transport of the oxidant and the fuel in the MMFC system also need to be remedied to shrink the diffusive mixing region of the two streams because this dissuasive interface between the streams is the only thing that provides the function of a membrane. The diffusive mixing region is a major performance-limiting factor. The diffusive mixing region degrades the overall MMFC performance by (a) mitigation of the oxidant/fuel concentrations, which leads to decrease in current density; (b) resistance to ion transport, which increases the ohmic losses; and (c) fuel crossover from the anodic to the cathodic channel, which decreases the open-circuit potential. Therefore, the fundamental elements to enhance the mass-transport in an MMFC system are reducing the diffusive mixing region between the oxidant and fuel and the depletion region at the surfaces of the electrodes. This can be achieved by modifying the flow configuration and electrode arrangement.

Various flow configurations of MMFCs have been studied. The flow configurations were reviewed by classifying them into six categories: (a) co-laminar flow MMFCs (CLFMMFCs), (b) single-stream MMFCs (SSMMFCs), (c) counter-flow MMFCs (CFMMFCs), (d) radial-flow MMFCs (RFMMFCs), (e) orthogonal-flow MMFCs (OFMMFCs), and (f) lateral-flow MMFCs (LFMMFCs). CLFMMFCs were further divided into five subcategories: (a) side-by-side stream, (b) vertical-layered stream, (c) multi-stream, (d) dual-pass, and (e) recirculation CLFMMFCs.

A concept map is outlined to develop a general understanding of the parameters affecting the flow configuration and how they impact the performance of an MMFC, as shown in Figure 1. The concept map provides a clear summary for understanding the related problems in MMFCs [30].

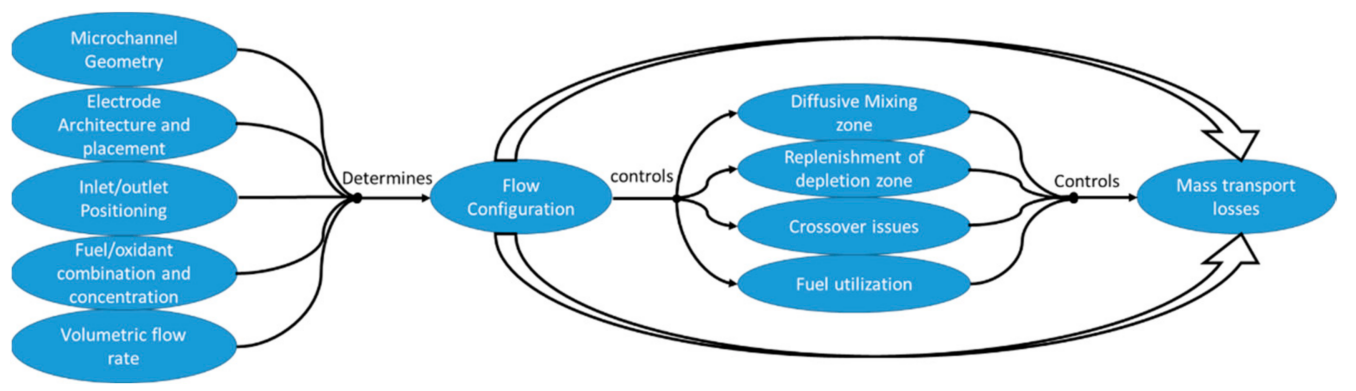

Figure 1. Concept map for the impact of flow configuration on the mass-transfer loss in MMFC.

\section{Fundamentals of MMFCs}

The fundamental electrochemical conversion principle of membrane fuel cells applies to MMFCs. The main difference is that the fuel-oxidant interface (the diffusive mixing region) plays the role of the membrane by transporting ions and separating the anodic and cathodic half-cells in a microchannel. Oxidant and fuel streams are inserted separately into the channel and create a fuel-oxidant interface when they come in contact and flow in the channel. The microchannel walls support the current collectors and electrodes coated with an appropriate catalyst, where electrochemical reactions occur mainly.

The fuel and oxidant streams are mixed with an ionic conductive electrolyte (acidic, alkaline, or mixed) to accomplish a uniform ionic transportation between the two anodic and cathodic channels. The electrolyte mixed with the fuel and oxidant streams contains hydroxide or hydrogen ions (basic or acidic solutions), which ensures the nature of working media in the MMFC, either acidic, alkaline, or mixed. Commonly, the microchannels have a characteristic length greater than $1 \mu \mathrm{m}$ and less than $1 \mathrm{~mm}$ [23], and the fluid flow within the microchannel is analyzed by microfluidics.

A set of steady-state conservation equations is used to numerically simulate MMFC operation to estimate the effects of ohmic, activation, and mass-transport losses on the performance of MMFCs. Microfluidic flows inside microchannels with smaller dimensions 
and lower velocities are characterized by low Reynolds numbers. The flow structure is represented by Navier-Stokes and continuity equations [31]. The hydroxide or hydrogen ions are supposed to be uniformly distributed in the anodic and cathodic compartments. The transportation of ions is controlled by electric migration from the anodic compartment to the cathodic compartment. The electric field is determined by the potential equation by quantifying the transport of charged species for the aforementioned conditions.

The velocity field determined using Navier-Stokes equations is used to calculate the transport of reactant species and the concentration distribution. The transport of reactants along the microchannel's characteristic length occurs through convection. It is necessary to remove the depleted reactant species near the electrodes, which is achieved by diffusive transport.

A low concentration of reactant species is the major cause of mass-transport losses. Mass-transport losses play a vital role in limiting the MMFC potential at higher current densities when an MMFC is working at lower flow rates due to slower replenishment of depleted reactants at the electrodes. The design and flow configuration of an MMFC play a vital role in decreasing mass-transport losses. When concentrations of reacting species are low, the diffusion rates and concentration gradients are considered linearly proportional [32]. Fick's law [31] is used to find the concentration distributions of the oxidant and fuel. In the electrochemical reactions, fuel and oxidant are oxidized and reduced over the anode and cathode, respectively, which results in electric current. The Butler-Volmer equation [33] is used to find the current density.

\section{Architecture and Fabrication}

Figure 2 shows MMFC design variations based on multiple flow configurations. This figure characterizes the strategic conceptual improvements in MMFCs to date. Different fabrication methods are used to achieve different flow configurations inside microchannels, and there are many ways of developing MMFC systems. The type of material, dimensions, and geometry influence the fabrication method of the system. MMFCs can be fabricated by cost-effective, well-recognized processes, such as photolithography, soft-lithography, and micro machining.

Figure 2a shows a CLFMMFC, where both the fuel and oxidant flow in a co-laminar way down the channel. The first CLFMMFC was proposed by Ferrigno et al. [13]. They fabricated a Y-intersection microfluidic channel having two inlets and a single outlet [13]. Hollinger and Kenis [34] shed light onto the fabrication and manufacturing of CLFMMFCs. A device was fabricated using soft-lithography with poly-dimethyl-siloxane (PDMS), which is used for multiple other microfluidic applications and devices. The electrodes were referred to as planar "flow-over" electrodes. They were placed on the bottom of the central channel, and the co-laminar flow interface was formed normal to the electrodes during operation. 


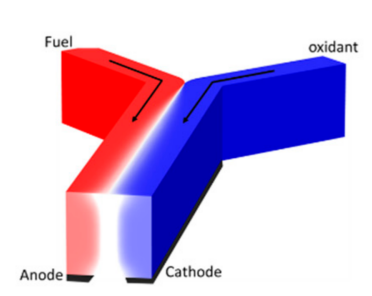

(a)

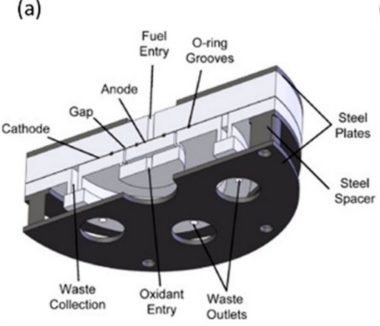

(e)

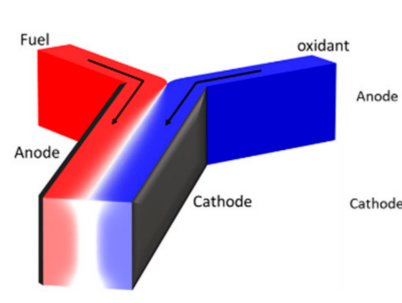

(b)

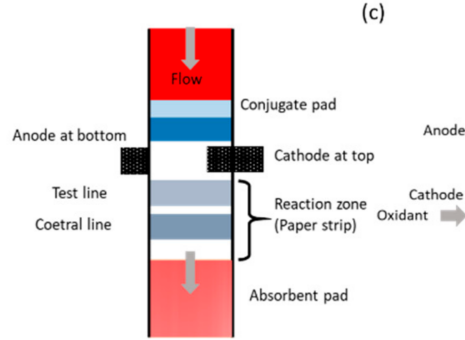

(f)

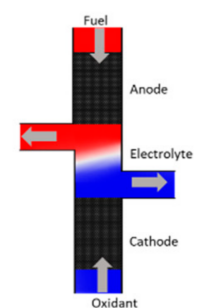

(d)

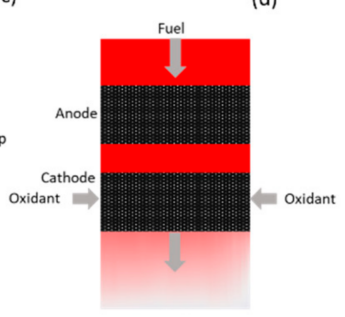

(g)

Figure 2. Evolution of MMFC: (a) side-by-side streaming co-laminar flow MMFC (CLFMMFC), (b) vertical-layered streaming CLFMMFC, (c) single-stream MMFC (SSMMFC), (d) counter-flow MMFC (CFMMFC), (e) radial-flow MMFC (RFMMFC) (reprinted from ref. [35]. Copyright 2008 Elsevier), (f) lateral-flow MMFC (LFMMFC), and (g) orthogonal-flow MMFC (OFMMFC).

Since the electrodes are glazed on microfluidic channels and were parts of the same layer, this single-layer monolithic cell design tended to be integrated into on-chip systems and other MEMS devices [36]. Monolithic MMFCs with Y-shaped and T-shaped microchannels have been studied extensively [20,37-50]. Their simple fabrication, operation, and implementation have drawn attention from various research groups. Choban et al. [15] developed a similar MMFC, as shown in Figure 2b. They introduced vertical layers in the design, where two electrodes were placed along the microchannel walls, and an encapsulation layer was used to separate the electrode surfaces. Two additional plates were used for sealing the assembly. The "flow-over" electrodes were placed parallel to both the flows of fuel and oxidant and the co-laminar interface. Vertical-layer CLFMMFCs [15,18,34,51-59] have evolved considerably. Many MMFCs are now fabricated in this way and have a configuration with a high aspect ratio and multi-layer sandwich structure [34]. The fabrication of such MMFCs is cheap with a simple design, no lithographic method is involved in the fabrication, and the structure is easier to stack. However, these MMFCs are difficult to integrate with on-chip devices.

The SSMMFC [60] shown in Figure $2 \mathrm{c}$ is fabricated using photolithography and sputtering (a lift-off process). Film electrodes are patterned by photolithography and sputtering on glass slides. SSMMFCs use a simple membraneless planar structure with inexpensive catalysts, which ensures flexible designs that are easily stackable and integrated for on-chip applications. The CFMMFC [61-63] shown in Figure 2d keeps the fuel and oxidant separated by a non-reacting electrolyte stream, which lets them flow to different outlets without mixing diffusively. The original CFMMFC proposed by Salloum et al. [61] uses three polymethylmethacrylate (PMMA) layers, which were fabricated by a $\mathrm{CO}_{2}$ laser ablation system. The bottom layer serves as a current collector, and Toray carbon paper in the middle serves as porous flow-through electrodes. CFMMFCs have been extensively studied [61-64] while considering minimal diffusive mixing, which decreases the masstransport loss significantly. Also, a CFMMFC can be investigated for larger chamber volume and electrode area to generate higher power density for portable applications.

The RFMMFC developed by Salloum et al. [35] (Figure 2e) differs from conventional CLFMMFCs because the fuel and oxidant flow in series instead of parallel. They fabricated an RFMMFC using a stainless-steel disk sandwiched between two milled PMMA plates. Flow-through electrodes based on Toray carbon paper were coated with Pt black catalyst. Current was collected by platinum wire connected to the electrodes. The RFMMFCs avoid 
advection of streams in parallel. This concept was also used by various researchers $[65,66]$ to improve the mass-transport in MMFCs.

The LFMMFC shown in Figure $2 \mathrm{f}$ uses paper-based material. Chromatography paper (Whatman grade 1) is conventionally used for fabrication, which allows reactants to flow laterally by means of capillary action. Various fabrication methods have been used to construct LFMMFCs, such as (i) photolithography, screen printing [67-69], (ii) wax printing, stencil printing [70], (iii) wax printing, screen printing, origami [71], (iv) wax printing, sputtering [72], (v) cutting, stacking [73], (vi) origami, molecular imprinting [74], (vii) wax printing, pencil drawing [75], and (viii) ink-writing [76]. These fabrication methods have been used for different purposes, design features, and applications of LFMMFCs.

The OFMMFC shown in Figure $2 \mathrm{~g}$ was proposed by Hayes et al. [77] and allows fuel mixed with electrolyte to travel orthogonally to electrodes housed in Teflon-lined stainless-steel cylinders. It was fabricated using a machining process, and Toray paperbased disks were placed inside the cylinders as electrodes. OFMMFCs are very expensive to fabricate, but are less compatible for on-chip integration. Therefore, they have rarely been investigated further for commercialization and portable applications.

\section{Design and Flow Configurations}

The interfacial diffusive region of the fuel and oxidant performs as a pseudo-membrane. It acts as a conductive medium for ions and controls the mixing of the oxidant and fuel without crossover across the fuel cell. In short, MMFCs benefit from microfluidics to remove the membrane from conventional fuel cells and hence eliminate membrane-based problems, such as membrane fouling, water management, and damage [13,78]. Elimination of the membrane reduces the fuel cell's size and provides flexibility in cell fabrication, design, and miniaturization [13,79]. Additionally, the composition and combination of the oxidant and fuel streams can be customized to take full advantage of the anodic and cathodic reaction kinetics [57]. The design issues related to sealing the packaging is partially resolved because the oxidant and fuel flow through a single channel. MMFCs are compatible with lab-on-chip devices and other microfluidic systems as power sources.

The microfluidic channel is a major component of an MMFC, which is mainly made up of plastic materials, such as PMMA, PDMS, and silicone sheets. The substrate accommodates the reactant species, electrodes, and current collectors. Furthermore, MMFCs with paper-based or fabric-based substrate are also being studied. The syringe or peristaltic pumps are mainly employed to deliver fuel and oxidant streams into microchannel [20,80-82]. But, this method adds cost and complexity into the system. To simplify the MMFC system and reduce parasitic energy consumption, passive pumps without electricity input, such as gravity pump [83], osmotic pump [84], evaporation pump [85], and in-situ gas pump [86], have also been proposed to replace the active electric pump. Furthermore, paper-based MMFCs do not require pumping as reactant streams travel downstream by capillary action [87]. The gravity pump siphons the electrolyte to a waste container placed at lower altitude from the reservoir; this phenomenon requires static working conditions and the flow rate decreases gradually. The osmotic pump draws the electrolyte continuously across a semipermeable membrane utilizing the concentration difference of water molecule. It can be integrated to portable devices and provide a stable flow rate. The evaporation pump draws the waste out of an MMFC by employing a volatile solvent to create negative pressure at the exit of the microchannel in a small chamber. In-situ gas pumping is suitable for MMFCs, which generate gas during anodic reaction (i.e., $\mathrm{CO}_{2}$ in a formic acid MMFC). The generated gas draws the electrolyte automatically alongside towards the outlet. However, the flow rate is periodical due to the growth of gas bubbles.

Lower fuel usage per single pass, ohmic losses, and mass-transport losses significantly contribute to decreasing the power output, and are thus regarded as the foremost disadvantages of MMFCs. Various factors are concerned with the mass transport losses as explained in Figure 1. Furthermore, the factors defining the ohmic losses are detailed 
in Section 6. With both streams and electrodes in a single channel of an MMFC, the flow configuration significantly affects the performance. Several investigations were performed to find the effects of the flow configuration and electrode structure/arrangement on the fuel cell performance. All MMFC designs use alike oxidants and fuels, and can be fabricated by standard orthodox manufacturing methods with identical precision. All the proposed designs can use either acidic or alkaline electrolytes.

\subsection{CLFMMFCS}

Figure 3 illustrates multiple modifications and significant developments made in CLFMMFCs in the past two decades since the first model was developed [13]. All of the described designs use co-laminar flow of the oxidant and fuel, but they differ in the architecture, structure, or arrangement of the electrodes along the microchannel. The reactant streams in the CLFMMFC come in contact with electrodes in two configurations: side-by-side streaming, where a vertical fuel-oxidant interface develops side by side with a horizontal depletion region (Figure 3a), and vertical-layered streaming, where a vertical fuel-oxidant interface and depletion region develop down the channel in the MMFC (Figure 3b).

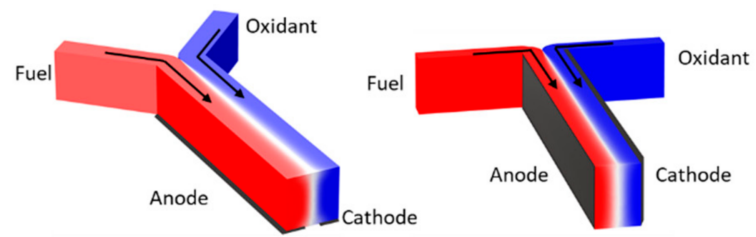

(a)

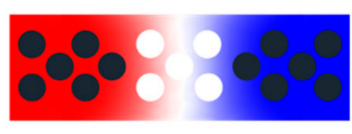

(d)

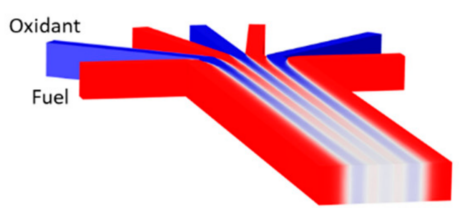

(g) (b)

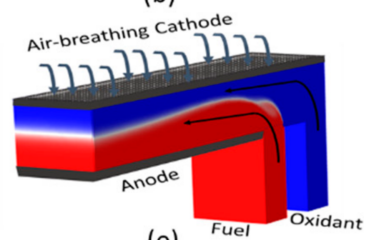

(e)

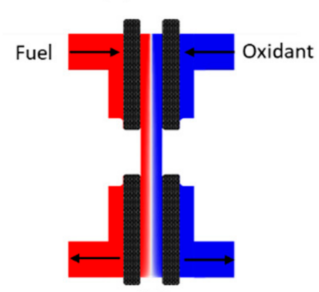

(h)

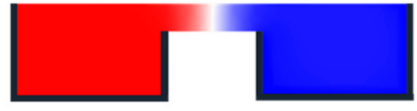

(c)

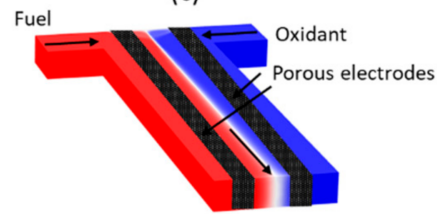

(f)

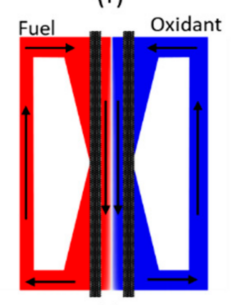

(i)

Figure 3. Various CLFMMFCs (black color indicates electrode, and red and blue colors indicate reactant streams); (a) CLFMMFC with side-by-side streaming with flow-over electrodes, (b) CLFMMFC with vertically-layered streaming with flow-over electrodes, (c) CLFMMFC with bridge-shaped microchannel cross-section and flow-over electrodes architecture, (d) CLFMMFC with graphite rods as electrodes (cross section), (e) CLFMMFC with air-breathing electrodes, (f) CLFMMFC with flowthrough electrodes, (g) multi-stream CLFMMFC, (h) CLFMMFC with recirculation (cross section), and (i) CLFMMFC with dual pass (cross section).

The fuel utilization in CLFMMFCs is greatly dependent upon the reactant flow rate and concentration, and can be described by the following equation:

$$
\eta=\frac{j}{\mathrm{nFCQ}}
$$

where $\mathrm{j}$ is the current at a flow rate $\mathrm{Q}, \mathrm{n}$ is the number of electrons transferred, $\mathrm{C}$ is the fuel concentration, and F is the Faraday's constant. This fuel utilization can be increased by flowing fuel of low concentration at a lower flow rate. Since the flow rate and concentration 
determine the reaction residence time, mass-transport due to diffusion at the fuel/oxidant interface, reactant's replenishment rate, and product's advection. Nevertheless, it is also beneficial to expose the reactants to the largest possible reactive surface of electrodes. Larger surface area enlarges the reaction site, and reduces depleted layer, which subsequently increases the extracted current, whereas the fuel cell needs to be designed to house larger electrode area

\subsubsection{CLFMMFCs with Side-By-Side Streaming}

In the side-by-side flowing of the fuel and oxidant streams, the electrodes initially used were "flow-over" electrodes, and the fuel-oxidant interface formed perpendicular to the electrodes [13], as shown in Figure 3a. With a Y-shaped or T-shaped microchannel, this CLFMMFC architecture has led to numerous studies [20,37-50]. Its simple operation and implementation let researchers investigate CLFMMFCs using biofuels with enzymatic or microbial catalysts $[40,47-50]$.

\subsubsection{CLFMMFCs with Vertical-Layered Streaming}

In vertical-layered streaming of the fuel and oxidant, the electrodes are placed on the channel walls parallel to the mixing layer [15], as shown in Figure 3b. This type of verticallayered CLFMMFC has advanced extensively [15,18,34,51-59,88]. It is well-suited for stacking and takes advantage of low-cost fabrication techniques with no lithographic method for fabrication. Considering the lower fuel utilization and ineffective mass-transport, multiple flow-over electrode arrangements have been studied for vertical-layered CLFMMFCs. Vertical-layered CLFMMFCs have been studied with various flow-over type electrodes, such as an array of electrically insulated graphite rod electrodes [78], a cylindrical anode [89-91], a grooved electrode surface [92,93], a tapered electrode [32], and extended electrodes [94].

To enhance the fuel utilization in vertical-layered CLFMMFCs, improved designs of channel/electrodes were used to provide effective area for electrochemical reactions, as shown in Figure 3c,d. Montesinos et al. [43] proposed a microchannel with a bridgeshaped cross section, as shown in Figure 3c. The microchannel with bridge-shaped cross section effectively isolates the diffusive interfacial zone and depletion zone, reduces the fuel crossover, and enhances the maximum power density and fuel utilization in CLFMMFCs. Similarly, Kjeang et al. [78] proposed a CLFMMFC using multiple graphite rods as anodes and cathodes, as shown in Figure $3 \mathrm{~d}$. The insulated graphite rods in the center of the microchannel prevent fuel crossover and enhance the performance.

The flow-over designs let the oxidant and fuel streams flow over the planar electrodes, where they contact the catalytic layer and contribute to reactions. Owing to the insufficient convective mass-transport, a region known as the depletion boundary layer develops over both electrodes, which comprises reactants with low concentration. The depletion boundary layer prevents the reactants from reaching the electrodes' reactive surfaces, which subsequently decreases the reaction rate and ultimately influences the performance of the CLFMMFC. Therefore, a thinner depletion boundary layer over an electrode is favorable [15]. The thinner depletion drives more fresh reactants towards the active surface of the electrode.

An air-breathing type electrode was proposed by Jayashree et al. [16]. Air-breathing electrodes minimize the thickness of the depletion boundary layer and generate a sharper concentration gradient, which results in a higher flux of reactants through the depletion region. They employed an air-breathing cathode electrode by substituting the graphite cathode with a porous gas diffusion electrode (GDE) hydrophobic in nature. The reduction occurring at the GDE consumes oxygen from ambient air, as shown in Figure 3e. The air-breathing electrodes can be used in a CLFMMFC with H-shaped microchannel [95-98], but a Y-shaped microchannel [16,17,89,99-102], T-shaped microchannel [103-105], and F-junction microchannel with the inlets located on the same side have been studied more extensively. When coupled with the air-breathing electrodes, the products exit through a 
common outlet $[16,90,91,106-110]$. The air-breathing electrode concept was adapted from metal-air batteries [60] or commercially available PEM fuel cells [111] for MMFCs.

Kjeang et al. [82] demonstrated flow-through electrodes for a CLFMMFC, where the reactant stream passes through the three-dimensional porous electrode that includes the active catalytic area, as shown in Figure $3 \mathrm{f}$. The flow-through porous electrodes primarily eliminate reactant-depletion complications at the electrodes and thus maximize the fuel utilization. The effective convective or diffusive mass-transport through porous electrodes continuously replenishes the depleted reactant concentration in the boundary layer. This results in better fuel utilization and enhances the power output. Goulet et al. [112] proposed an in-operando deposition of flow-through electrodes by employing temporarily suspended carbon nanotubes (CNTs) during the cell operation to enhance the reaction kinetics and mass transportation. By in-operando deposition of CNTs, they enhanced the surface area for electrochemical reaction and achieved a power density of $2010 \mathrm{mWcm}^{-2}$, which is the highest among all the MMFCs developed till date.

Several designs have been studied for side-by-side streaming combined with flowthrough porous electrodes [113-116]. It has been illustrated in the literature that porous flowthrough electrodes can also be used with vertical-layered CLFMMFCs [103,112,117-119]. Li et al. [120] used a vertical-layered CLFMFC with a flow-through electrode configuration to increase the fuel cell performance. Flow-through electrodes have been investigated in different combinations of air-breathing and flow-over electrodes [95-98,100,101,104,106,108,110]. Shaegh et al. [17] reviewed different types of electrode architecture and their effects on the performance in detail. Additionally, CLFMMFCs have been investigated in derivate studies with modifications in the original flow configuration and were extended to multiple laminar flows (Figure 3g) [44,121], innovative recirculation (Figure 3h) [122], and dual-pass configurations (Figure 3i) [123].

In essence, there is a trade-off between the fuel utilization and power density of a CLFMMFC. With an increase in power density by increasing fuel/oxidant flow rate, reducing channel length, etc., the fuel utilization tends to decrease. To improve the fuel utilization in flow-over designs without sacrificing power density, a better design of electrodes needs to be employed in the channel to explore more active areas to reactants for electrochemical reactions. These electrode architectures have been developed to replenish the depletion region quickly. The porous flow-through type electrodes and air-breathing electrodes have been implemented to enhance both the fuel utilization and power density.

The effective convective/diffusive mass-transportation through three-dimensional porous electrodes replenishes the concentration boundary layer continually, which subsequently increases the fuel utilization and results in a greater power output. The electrodes with flow-through architecture provide uniform reactant's concentration over the reactive site for electrocatalysis. The lower concentration and diffusivity of dissolved oxygen as oxidant passively carry out the replenishment of the depletion region over cathode. Thus, replacing a flow-over type cathode with an air-breathing cathode provides oxidant form ambient air with higher concentration and diffusivity, which replenish the depletion boundary layer effectively.

\subsubsection{Multi-Stream CLFMMFCs}

Sun et al. [44] introduced a CLFMMFC using multiple streams of laminar flow to isolate the oxidant and fuel streams by inserting a third stream of electrolyte between them, as shown in Figure 4a. The configuration with an electrolytic stream ensured the prevention of direct contact between the fuel and oxidant, which enhanced the fuel utilization and minimized the fuel crossover. Khabbazi et al. [94] performed a numerical investigation of a multi-stream laminar flow in an MMFC. Most of the CLFMMFCs using air-breathing cathodes for oxidant reduction introduce an electrolytic stream to avoid fuel crossover. Kjeang et al. [124], investigated a multi-stream MMFC with a flow-through porous electrodes architecture, as shown in Figure 2b. They used a gaseous fuel and oxidant with a liquid electrolyte. 


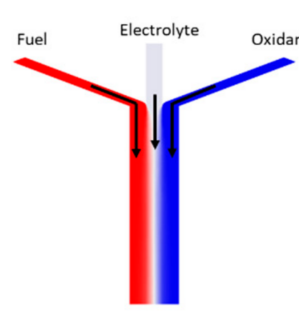

(a)

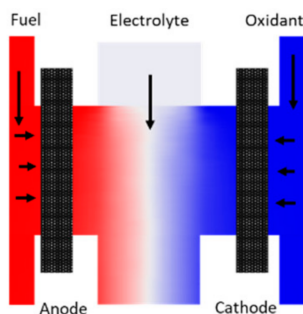

(b)

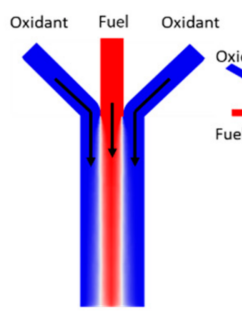

(c)

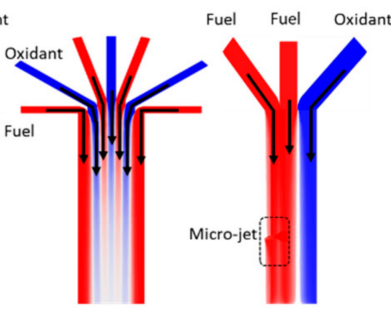

(d)

(e)

Figure 4. CLFMMFCs with multi-stream configurations: (a) multi-stream MMFC with an extra electrolytic stream, (b) multi-stream MMFC with extra electrolytic stream and flow-through type electrodes (indicated by black color), (c) multi-stream MMFC with oxidant-fuel-oxidant configuration, (d) multi-stream MMFC with multiple fuel and oxidant streams, and (e) multi-stream MMFC with an immersed micro-fuel jet.

Tanveer and Kim [66] investigated the multi-stream laminar flow of an oxidant-fueloxidant configuration for a CLFMMFC, as shown in Figure 4c. Lee and Ahn [121,125] used the multi-stream laminar flow concept and put together multiple fuel and oxidant streams in parallel to achieve a planar stacked structure, as shown in Figure 4d. Ahmed et al. [126] proposed a trident-shaped CLFMMFC where the fuel, oxidant, and an electrolyte are inserted through three inlets to improve fuel utilization by using multi-stream laminar flow. Wu et al. proposed a CLFMMFC with continuous multi-stream flow through cotton threads [127].

Zhou et al. [101] used the multi-stream concept and fed a portion of fuel perpendicular to the anode to create an immersed micro-jet. The other portion of the fuel flow was parallel to the anode. The part of fuel flowing along the anode generates a concentration boundary layer, which is replenished by the fuel micro-jet directed perpendicularly toward the anode, as shown in Figure 4e. The micro-jet created by immersed fuel improved the peak power density by $40.9 \%$. A CLFMMFC where multiple streams of fresh reactants are inserted via periodically placed multiple inlets was also presented to enhance fuel utilization and rate of the electrochemical reaction $[54,94]$.

Kwok et al. [128] and Lu et al. [129] employed air breathing cathode and fuel breathing anode with single and double electrolytic streams, respectively. Kwok et al. [128] designed a novel solar assisted dual-fuel MMFC employing methanol and hydrogen. They carried out an in-situ hydrogen generation by the photocatalysis of methanol. They achieved a peak power density of $210 \mathrm{mWcm}^{-2}$. Whereas, Lu et al. [129] investigated a dual electrolytic stream (i.e., both acidic and alkaline) switchable MMFC. They designed a switchable $\mathrm{pH}$ environment by coupling fuel with alkaline media and the oxidant with acidic media in fuel cell mode, while the media was switched in electrolysis mode. So, they achieved a peak power density and maximum current density of 1300 and $3600 \mathrm{mAcm}^{-2}$, respectively, in the fuel cell mode. This was possible by achieving an enhanced output voltage by carrying out oxidation at higher $\mathrm{pH}$ (i.e., acidic) and carrying out reduction at lower $\mathrm{pH}$ (i.e., alkaline).

Cascading multiple streams in a single channel increase power density, but reduce the freedom to employ electrodes involving complex architecture, which leads toward enhancement of both power density and fuel utilization. Therefore, multi-stream CLFMMFCs have not been investigated by employing flow-through anode with air-breathing cathode. However, the air-breathing cathode can be integrated by feeding the oxidant perpendicular to the flow of fuel, which may give an option to accommodate multiple air-breathing cathodes with flow-through anode arrangement.

\subsubsection{Dual-Pass CLFMMFCs}

The dual-pass idea was first used by Lee et al. [123] to develop the first membraneless microfluidic redox battery (MRB), where two electrodes are split into two sections for insitu regeneration and to use the reactants efficiently, as shown in Figure 5a. The upstream 
and downstream portions were characterized discretely. Dual-pass CLFMMFCs improve the performance by using the same in-situ regeneration by connecting two CLFMMFCs in parallel. Ibrahim et al. [130] proposed a cell design with two separate portions featuring flow-through electrodes to enhance the power density. Ibrahim and Kjeang [131] used a dual-pass CLFMMFC with non-aqueous electrolyte and achieved a power density of $550 \mathrm{mWcm}^{-2}$, which is almost two times greater than the power density produced by conventional non-aqueous CLFMMFCs. Ho and Kjeang [132] created an array of dual-pass CLFMMFCs and generated a power density of $1206 \mathrm{mWcm}^{-2}$ using a bilateral array design, as shown in Figure $5 b$.

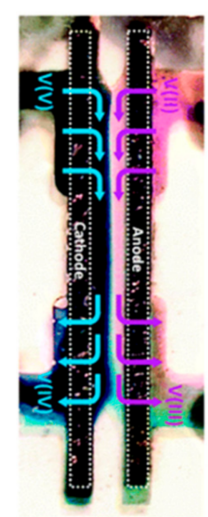

(a)

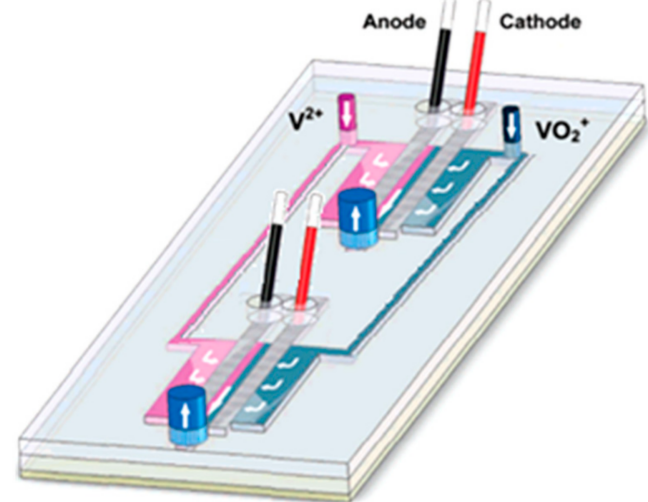

(b)

Figure 5. Duel-pass configurations: (a) dual-pass vanadium redox flow battery (reprinted from ref. [123]. Copyright 2013 RSC), and (b) dual-pass MMFC [132].

\subsubsection{CLFMMFCs with Recirculation}

Recirculation is another way to carry out in-situ regeneration in CLFMMFCs and to use reactants efficiently. Recirculation is carried out to transport the unused reactants at the outlet of a microchannel to the inlet for reuse. Goulet and Kjeang [122] fabricated a Y-shaped microchannel with flow-through electrodes for reactant recirculation and a dual-pass configuration, as shown in Figure 6. They found that the reactant recirculation is a useful strategy to minimize reactant crossover, improve reactant utilization, and achieve higher power density in CLFMMFCs. However, recirculation has not been studied extensively for CLFMMFCs.
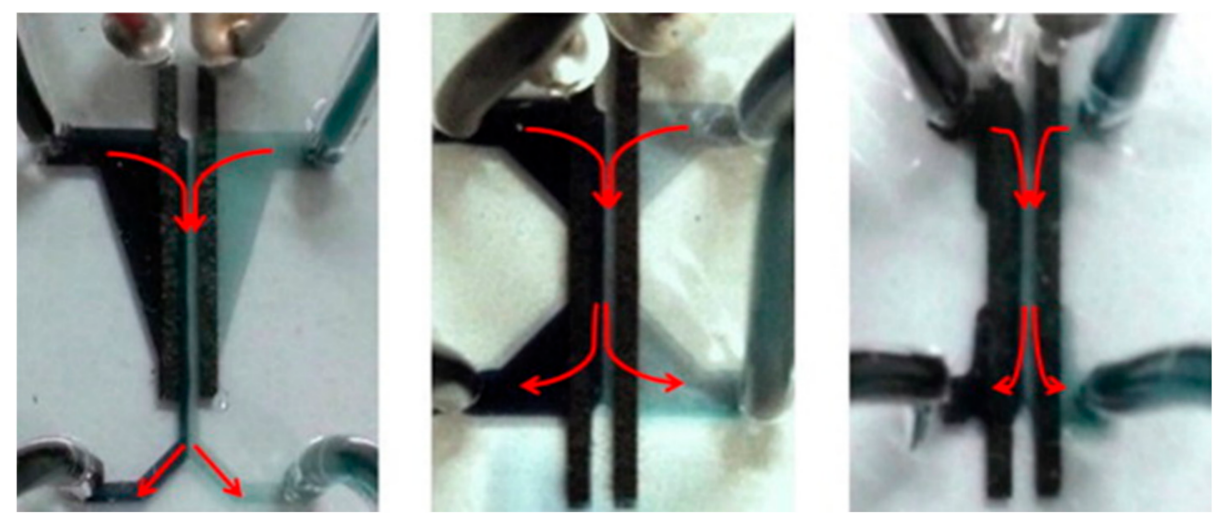

Figure 6. Reactant recirculation in MMFC (reprinted from ref. [122]. Copyright 2014 Elsevier).

\subsection{SSMMFCs}

Hydrogen peroxide $\left(\mathrm{H}_{2} \mathrm{O}_{2}\right)$ is used as an oxidant in MMFCs. Additionally, hydrogen peroxide can react as fuel by donating electrons and can thus perform a dual role [133]. The dual roles of $\mathrm{H}_{2} \mathrm{O}_{2}$ can be achieved by selective catalysis of the electrode: silver nanowires 
accomplish oxidation of $\mathrm{H}_{2} \mathrm{O}_{2}$, while CNTs support Prussian blue to achieve the reduction of $\mathrm{H}_{2} \mathrm{O}_{2}$. This dual nature of hydrogen peroxide lays a path toward the development of SSMMFCs. This approach is applicable and limited to mixed pairs of fuel and oxidant that show very high electro-kinetic for a single electrolyte and do not react spontaneously. As fuel and oxidant solutions are mixed in a single stream, the issue of fuel crossover is eliminated in this type of MMFC.

Sung and Choi [60] proposed an SSMMFC using an alkaline solution. They employed a silver oxide cathode for the reduction of hydrogen peroxide, and a nickel hydroxide anode to oxidize methanol. The mild catalytic activity and reaction kinetics resulted in a very low open-circuit voltage $(\mathrm{OCV})$ of around $0.12 \mathrm{~V}$ and a power density of around $0.03 \mathrm{mWcm}^{-2}$. The power density was improved by reducing the electrode spacing, which decreased ohmic losses and improved mass-transport.

Togo et al. [134] developed an SSMMFC using a bioanode with vitamin K3-mediated glucose as the fuel and a glucose dehydrogenase enzyme as the oxidant, as shown in Figure 7a. Their SSMMFC generated a maximum power density of $32 \mu \mathrm{Wcm}^{-2}$ at $0.29 \mathrm{~V}$ when $5 \mathrm{mM}$ glucose (fuel) was inserted at a flow rate of $1 \mathrm{mLmin}^{-1}$. Recently, Togo et al. [135] used a bilirubin oxidase-adsorbed biocathode instead of a Pt cathode. The maximum power density generated was comparable with that of a previous device [134].

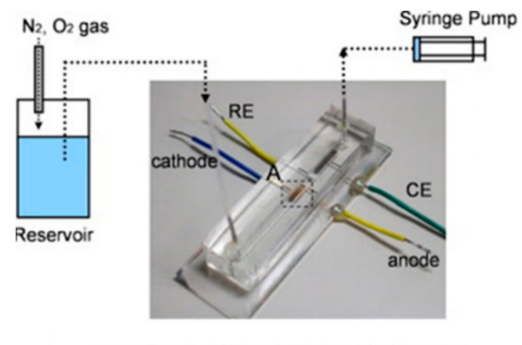

(a)

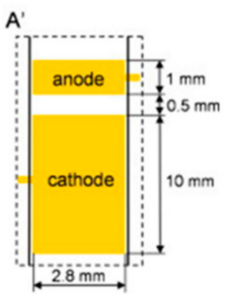

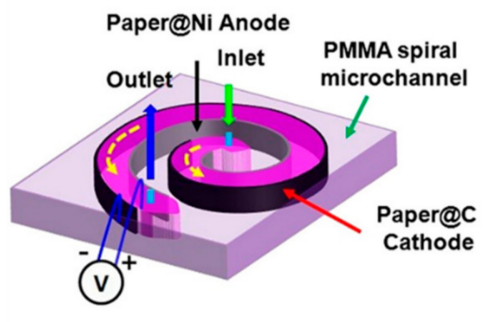

(b)

Figure 7. SSMMFCs: (a) SSMMFC with anode and cathode in single channel separated by a gap (reprinted from ref. [135]. Copyright 2008 Elsevier) and (b) a spiral-shaped SSMMFC (reprinted from ref. [136]. Copyright 2019 Wiley Online Library).

Arun et al. [136] developed a vanadium-based spiral-shaped SSMMFC using a carbon cathode and $\mathrm{Ni}$ anode with a fuel-electrolyte mixture of $\mathrm{VOCl}_{3}$ and diluted $\mathrm{H}_{2} \mathrm{SO}_{4}$, as shown in Figure 7b. The spiral-shaped microchannel was built on a 1.5-mm-thick PMMA sheet with a laser engraving machine. They found that the low pressure drops in the spiral-shaped channel with uniform ion distribution enhanced the mass-transport. This device generated a maximum current density and power density of about $51 \mathrm{mAcm}^{-2}$ and $10 \mathrm{mWcm}^{-2}$, respectively. The SSMMFCs fabricated on PMMA or PDMS have very low power densities and OCVs, so they have not been studied extensively. However, LFMMFCs with similar flow configuration have been studied extensively (as shown in Section 4.5).

\subsection{CFMMFCs}

Salloum and Posner [60] proposed a CFMMFC with vanadium redox species serving as the oxidant and fuel. The configuration relied on multiple streams, as proposed by Sun et al. [43]. Sun et al. [43,44] used multiple streams in a co-laminar flow configuration, while Salloum and Posner [61] used multiple streams in a counter-flow configuration, as shown in Figure 8a. The CFMMFC prevents the fuel and oxidant from mixing in three ways: (i) using an ion conducting electrolytic stream at the interfacial diffusive region of the fuel and oxidant, (ii) using hydrodynamics to avoid mixing at the fuel and oxidant interface, and (iii) collecting the fuel and oxidant independently via distinct outlets, which also ensures their possible recirculation and reuse, as shown in Figure 5a. CFMMFCs reduce the thickness of diffusive mixing zone and fuel crossover significantly in comparison with CLFMMFCs. 


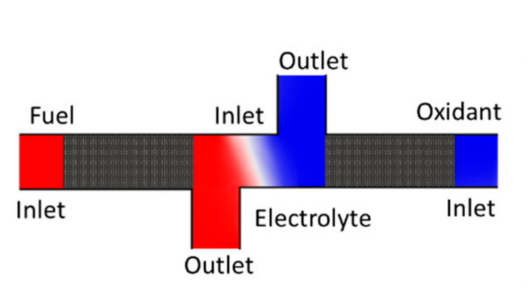

(a)

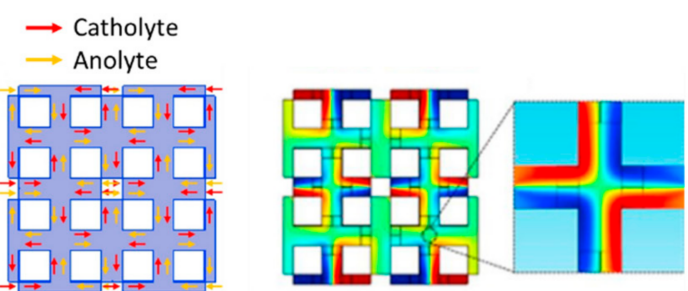

(b)

Figure 8. CFMMFCs: (a) CFMMFC with fuel and oxidant inlets and an extra electrolytic inlet, and (b) CFMMFC network with multiple inlets and outlets (reprinted from ref. [137]. Copyright 2018 Elsevier).

Lu et al. [137] proposed a state-of-the-art upscaling approach for a CFMMFC network (Figure 8b). They introduced a counter-flow-based dual-electrolyte protocol and observed that a counter-flow pattern enhances the reactive area for reactants. This approach was further investigated numerically by $\mathrm{Lu}$ et al. [138]. Wang et al. [139] investigated an airbreathing cathode in a CFMMFC. Xu et al. [140] studied a CFMMFC for formic acid and oxygen streams at different flow rates and achieved a fuel utilization of $91.4 \%$ for formic acid at $1 \mu \mathrm{Lmin}^{-1}$.

Wang et al. [141] investigated and compared a CLFMMFC and CFMMFC experimentally and numerically. The experimental study found that the CLFMMFC produced an excellent peak power density of $2.9 \mathrm{mWcm}^{-2}$, while the CFMMFC generated a peak power density of around $1.6 \mathrm{mWcm}^{-2}$. CFMMFCs were further investigated in derivative studies to improve the performance [61-64,141,142].

CFMMFCs improve the power density by reducing the diffusive mixing and fuel crossover and enhancing ionic conduction, while fuel utilization is sacrificed largely. Salloum et al. [61] found that the fuel utilization dropped drastically with a change in the flow rate from $50 \mu \mathrm{Lmin}^{-1}$ to $300 \mu \mathrm{Lmin}^{-1}$, while the power increase was not significant. They found a $20 \%$ increase in power density, whereas fuel utilization dropped by $91 \%$.

\subsection{RFMMFCs}

Manipulation of the fuel and oxidant's transport patterns in MMFCs is vital to reduce the mass-transport losses and achieve higher performance. In RFMMFCs, the main flow splits into two halves, which travel down the channel and are directed opposite to each other. Radial flow alleviates the effects associated with excess channel length. Radial flow tailors and reduces the overall diffusive mixing and depletion regions to break the size limitation.

Salloum et al. [35] conducted a study with a novel MMFC design using a disk-shaped flow-through anode and ring-shaped flow-through cathode. The fuel and oxidant were inserted radially, as shown in Figure 9a. Fuel injected into the porous anode splits into two halves around the central line, while oxidant is injected from two different inlets, as shown in Figure 9a. They found that increases in the flow rate and concentration of the electrolyte reduced the mass-transport and ohmic losses in the RFMMFC, which resulted in maximum current and power densities. By independently controlling the fuel and oxidant flow rates, the fuel utilization could be enhanced by up to $58 \%$. Increasing the electrolytic concentration increased the maximum power density from 1.5 to $3 \mathrm{mWcm}^{-2}$.

Tanveer and Kim [66] investigated an RFMMFC with various inlet locations along the microchannel to divide the active channel length into two halves and reduce the development length of the mixing layer. As shown in Figure 9b, placing inlets at the middle of the microchannel reduces the thicknesses of the diffusive mixing and depletion regions at the outlets, thus reducing the mass-transport losses and enhancing the power and current densities by multiple times [66]. Tanveer and Kim [143] used co-laminar flow and radial-flow simultaneously in an MMFC with multiple inlets, as shown in Figure 9c, 
which indicates a four-inlet channel. They found that eight inlets could increase the current density by 15 times in comparison with a conventional MMFC with two inlets.

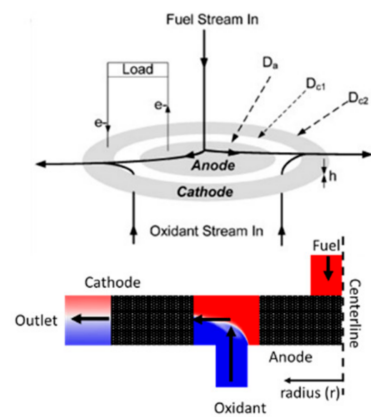

(a)

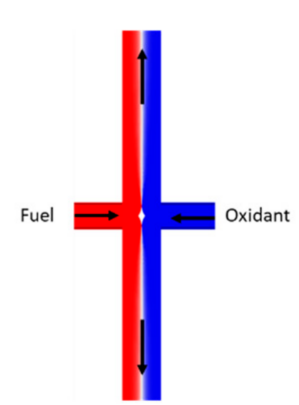

(b)

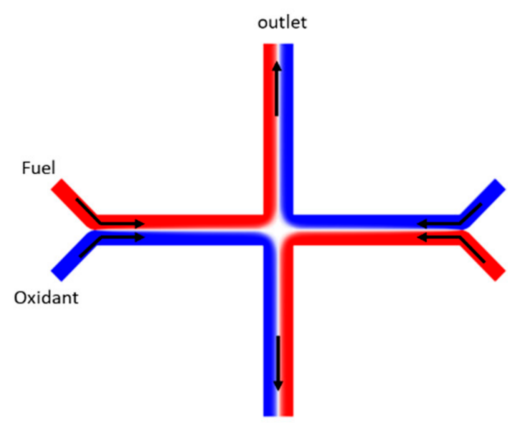

(c)

Figure 9. RFMMFCs: (a) sequential RFMMFC (reprinted from ref. [35]. Copyright 2008 Elsevier), (b) RFMMFC with flow-over type electrodes, and (c) combined CLFMMFC and RFMMFC.

Li et al. [144] investigated an RFMMFC with flow-through porous electrodes. They found that a single fuel cell with a fuel and oxidant concentration of $2 \mathrm{~mol} \cdot \mathrm{L}^{-1}$ and flow rate of $300 \mu \mathrm{Lmin}^{-1}$ could produce a peak power of around $0.35 \mathrm{~mW}$ with $53.33 \%$ fuel utilization. Li et al. [65] proposed using novel partially modified porous electrodes with the outlet at the channel center. This approach divides the electrochemical reaction zone (depletion region) into two halves, and reactions are carried out near porous electrodes' outlet. The performance of the RFMMFC with the partially modified porous electrodes is analogous to that of a conventional MMFC with porous electrodes.

RFMMFCs provide better fuel utilization in comparison with CLFMMFCs and CFMMFCs. In MMFC with a co-laminar flow configuration, unused fuel and oxidant mix by diffusion form an interfacial zone, which subsequently decreases the maximum possible fuel utilization. The RFMMFCs pose the higher electrode surface area and reduce the length scale by splitting the stream into two directions, which reduce both depletion and mixing zones. The RFMMFCs have a distinct transport feature, which eliminates the linear diffusion interface responsible for reactant mixing and crossover in CLFMMFCs. The disc-shaped porous electrodes proposed by Salloum et al. [35] for sequential RFMMFCs enlarged the overall reaction surface area, which resulted in higher fuel utilization. In a sequential design, any unused fuel either mixes with oxidants and depletes them, or cross over to react at the cathode, which causes mixed potentials. Therefore, it is compulsory to ensure the complete utilization of the reactant in the sequential flow pattern requires traveling through both the electrodes, either by tuning the oxidant and fuel flow rate to avoid crossover, or pairing the fuel and oxidant with the catalysts where they essentially carry out oxidation and reduction.

\subsection{LFMMFCs}

Osborn et al. [145] illustrated that a paper strip allows two streams to flow in parallel. These streams were driven down the strip exclusively by the capillarity of cellulose paper pores without convective mixing. Using this phenomenon, Esquivel et al. [87] introduced an LFMMFC using methanol and $\mathrm{KOH}$. This type of laminar flow-based MMFC uses capillary action to make the fuel and oxidant streams flow inside a paper-based porous material, as shown in Figure 10a. Using paper-based lateral strips in MMFCs eliminates the need for external pumping. Therefore, LFMMFCs benefit from the capillarity of paperbased porous strips and the laminar flow of the fuel and oxidant. These LFMMFCs with a self-pumping property further ease miniaturization and assure straightforward integration as a power supply, rapid fabrication, and low-cost manufacturing. Table 1 summarizes the performance evolution of LFMMFCs. 


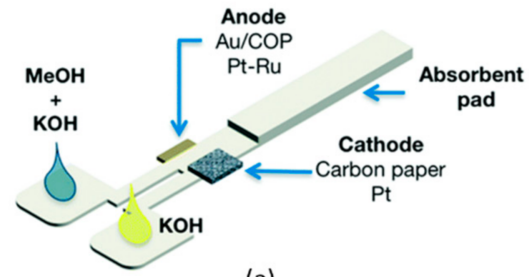

(a)

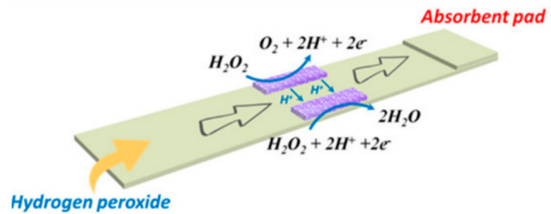

(b)

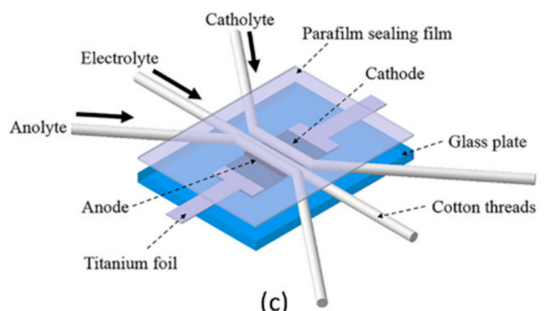

(c)

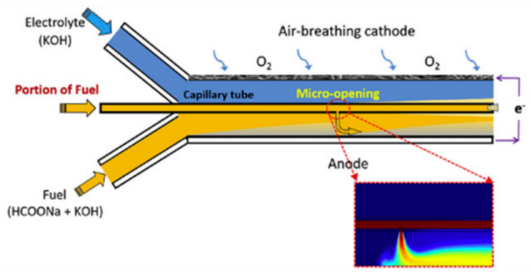

(d)

Figure 10. Multiple flow configurations adopted in LFMMFCs: (a) lateral co-flow MMFC on paper (reprinted from ref. [87]), (b) single-stream LFMMFC with hydrogen peroxide as fuel and oxidant (reprinted from ref. [148]. Copyright 2018 Wiley Online Library), (c) multi-stream MMFC with flow-through cotton threads (reprinted from ref. [127]. Copyright 2019 Wiley Online Library), (d) multi-stream MMFC with lateral flow through capillary tube to create micro-jet (reprinted from ref. [101]. Copyright 2020 Elsevier).

Table 1. Recent progresses made in lateral flow MMFCs.

\begin{tabular}{|c|c|c|c|c|c|}
\hline Reference & Fuel/Oxidant & Electrodes Type & OCV & Current Density & Power Density \\
\hline & & & & $I_{\max }\left(\mathrm{mAcm}^{-2}\right)$ & $P_{\max }\left(\mathrm{mWcm}{ }^{-2}\right)$ \\
\hline Rao et al. [146] & $\mathrm{HCOOH} / \mathrm{Air}$ & Graphite pencil stroked & & 1.51 & 0.174 \\
\hline Arun et al. [147] & $\mathrm{HCOOH} / \mathrm{Air}$ & Graphite pencil stroked & & 82 & 100 \\
\hline Yan et al. [148] & $\mathrm{H}_{2} \mathrm{O}_{2} / \mathrm{H}_{2} \mathrm{O}_{2}$ & Silver nanowires and carbon nanotubes & 1.09 & 10 & 0.88 \\
\hline Roman et al. [149] & Glucose $/ \mathrm{O}_{2}$ & Carbon & & & 0.0375 \\
\hline Shen et al. [150] & $\mathrm{KCOOH} / \mathrm{KOH}$ & Graphite Foils & 0.86 & & 7.10 \\
\hline Esquivel et al. [87] & $\mathrm{MeOH} / \mathrm{KOH}$ & Gold/Carbon Paper & 0.55 & 22.5 & 4.4 \\
\hline Jung and Ahn [151] & $\mathrm{V}^{2+} / \mathrm{VO}_{2}^{+}$ & Thin Graphene layer & & 30 & 15 \\
\hline Pasala et al. [152] & $\mathrm{NaBH}_{4} / \mathrm{VO}_{2}^{+}$ & & 2.1 & & 4.5 \\
\hline Chino et al. [153] & Urea/AgNO & Pt/Carbon & 1.54 & 4.3 & 0.91 \\
\hline Galvan et al. [154] & $\mathrm{HCOOK} / \mathrm{H}_{2} \mathrm{O}_{2}$ & $\mathrm{Pd} /$ Carbon & 1.1 & 11.5 & 2.53 \\
\hline Esquivel et al. [155] & $\mathrm{H}_{2} / \mathrm{O}_{2}$ & $\mathrm{Pt}$ & & 276 & 103.2 \\
\hline Chandra et al. [156] & $\mathrm{C}_{2} \mathrm{H}_{5} \mathrm{OH} / \mathrm{Cr}_{2} \mathrm{O}_{7}^{2-}$ & Stainless Steel/Carbon & 1.42 & 12 & 6.32 \\
\hline Lal et al. [157] & $\mathrm{N}_{2} \mathrm{H}_{4} \cdot \mathrm{H}_{2} \mathrm{O} / \mathrm{KMnO}_{4}$ & Multi walled carbon nanotubes & 1.85 & 7.5 & 3.58 \\
\hline Lal et al. [158] & $\mathrm{HCOOH} / \mathrm{KMnO}_{4}$ & Graphite & 1.3 & 1.4 & 0.57 \\
\hline González-Guerrero [159] & Glucose/Air & Glucose Oxidase/Laccase & 0.55 & 0.225 & 0.024 \\
\hline Purohit et al. [160] & $\mathrm{HCOOK} / \mathrm{AgNO}_{3}$ & $\mathrm{Pd} /$ Carbon & 1.14 & 16 & 4.1 \\
\hline Arun et al. [161] & $\mathrm{HCOOH} / \mathrm{O}_{2}$ & Graphite pencil stroked & 0.33 & 650 & 32 \\
\hline Copenhaver et al. [162] & $\mathrm{HCOOK} / \mathrm{KMnO}_{4}$ & Carbon/Graphite & 0.6 & 3.6 & 0.5 \\
\hline Ehteshami et al. [163] & $\mathrm{H}_{2} \mathrm{O}_{2} / \mathrm{H}_{2} \mathrm{O}_{2}$ & $\mathrm{Al} /$ Prussian Blue & 0.61 & & 0.81 \\
\hline Wang et al. [164] & $\mathrm{H}_{2} /$ Air & Carbon/Carbon Nanotubes & 0.93 & 8 & 4 \\
\hline Dector [165] & Glucose/Air & Glucose Oxidase/Carbon & 0.8 & & 0.16 \\
\hline Domalaon et al. [166] & $\mathrm{HCOOK} / \mathrm{H}_{2} \mathrm{O}_{2}$ & Stainless steel/Silver epoxy & 0.92 & 22.83 & 4.4 \\
\hline Liu et al. [167] & $\mathrm{HCOONa} / \mathrm{H}_{2} \mathrm{O}_{2}$ & Graphite rod & 1.44 & 56.6 & 20.7 \\
\hline Wu et al. [127] & $\mathrm{HCOONa} / \mathrm{O}_{2}$ & $\mathrm{Pt} /$ Carbon & 0.91 & 111.2 & 19.9 \\
\hline Zhou et al. [101] & $\mathrm{HCOONa} / \mathrm{O}_{2}$ & $\mathrm{Pd} /$ Carbon & 1.04 & 325 & 119.3 \\
\hline
\end{tabular}

The fabrication of LFMMFCs is very similar to that of lateral flow strips. They comprise a paper strip, absorbent pad, and conjugate pad. The anode and cathode are positioned on the top and bottom of the paper strip. LFMMFCs have been investigated for multiple flow configurations, as shown in Figure 10. The LFMFC used by Esquivel et al. [87] (Figure 10a) achieved a power density of $5 \mathrm{mWcm}^{-2}$. Dector et al. [165] investigated an LFMMFC installed in an HIV-test kit with blood as fuel. This paper-based LFMMFC attained a power density of $0.16 \mathrm{mWcm}^{-2}$. Rao et al. [146] investigated an LFMFC for various grades of cellulose paper using formic acid as fuel and sulfuric acid as the electrolyte. This 
LFMFC produced a maximum current density of $1.5 \mathrm{mAcm}^{-2}$ and peak power density of $0.18 \mathrm{mWcm}^{-2}$.

MMFCs have been extensively studied with the vanadium redox couple $\left(\mathrm{V}^{2+} / \mathrm{VO}_{2}^{+}\right)$. Jung and Ahn [151] considered the effectiveness of the couple and used it in LFMMFCs. However, an LFMMFC using vanadium redox species $\left(\mathrm{VO}_{2}^{+}\right)$has been reported before [152,168]. Pasala and Ramanujam [152] presented an LFMMFC that achieved a power density of $6 \mathrm{mWcm}^{-2}$. Yan et al. [148] reported a one-reactant and one-component single-stream LFMMFC that used $\mathrm{H}_{2} \mathrm{O}_{2}$ as the fuel and oxidant, as shown in Figure 10b. They used a silver nanowire anode and CNT cathode supported with Prussian blue to achieve the oxidation and reduction of $\mathrm{H}_{2} \mathrm{O}_{2}$. This MMFC eliminates the co-laminar flow and hence the fuel crossover, and it increases the maximum power density by up to $0.88 \mathrm{mWcm}^{-2}$.

Wu et al. [127] developed a cotton thread-based multi-stream LFMMFC to eliminate fuel crossover and the need for a syringe pump, as shown in Figure 10c. They fabricated this MMFC using cotton threads with sealing parafilm over a glass substrate and carbonpaper flow-through electrodes. Thread-based and fabric-based materials are alternatives to achieve lateral flow in microfluidic devices. They achieved a peak power density of $19.9 \mathrm{mWcm}^{-2}$ and maximum current density of $111.2 \mathrm{mAcm}^{-2}$.

Liu et al. [167] fabricated a thread-based multi-stream LFMMFC and achieved a maximum power density of $20.7 \mathrm{mWcm}^{-2}$. Zhou et al. [101] developed a multi-stream MMFC with an immersed micro-jet to replenish the depletion region and increase masstransport using lateral flow in a capillary tube, as shown in Figure 10d. They used a planar anode and air-breathing cathode made up of Toray carbon paper. They donned the immersed micro-jet by feeding a portion of the fuel into a titanium capillary tube and jetting fuel outside from a micro-opening perpendicular to the anode. The peak power density was $119.3 \mathrm{mWcm}^{-3}$. The proposed flow configurations for LFMFCs opened up new avenues to manipulate fluid flow and enhance mass-transport. LFMMFCs can be further investigated with dual-pass, radial-flow, and counter-flow configurations. Lateral flow strips can be cut into different shapes and can be cascaded to enhance the performance of the fuel cell.

\subsection{OFMMFCs}

Hayes et al. [77] proposed the orthogonal MMFC design shown in Figure 11, where the fuel and oxidant cross each other orthogonally. They investigated two different systems: one with oxygen mixed with $1.8 \mathrm{M}$ sulfuric acid as oxidant and hydrogen as fuel, and another with oxygen mixed with $1 \mathrm{M}$ potassium hydroxide as oxidant and methanol as fuel. The orthogonal flow design prevents mixing and enhances the mass-transport because the oxidant and fuel streams have no diffusive mixing and are delivered convectively to the reaction site. The peak power density was $46 \mathrm{mWcm}^{-2}$ with $42 \%$ fuel (methanol) utilization. However, no derivative studies for OFMMFCs are found in the literature.

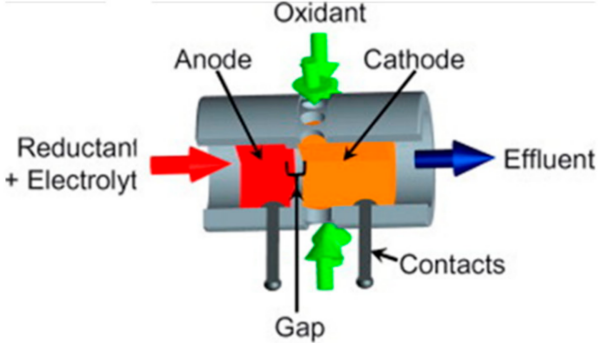

(a)

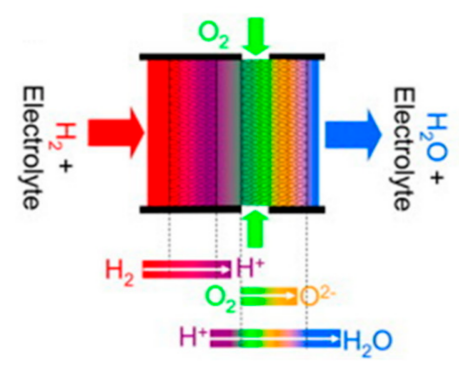

(b)

Figure 11. OFMMFC: (a) orthogonal flow design comprising porous electrodes separated by a gap, and $(\mathbf{b})$ fuel $\left(\mathrm{H}_{2}\right)$ oxidation at anode to $\mathrm{H}^{+}$, and oxygen $\left(\mathrm{O}_{2}\right)$ reduction to $\mathrm{O}_{2}{ }^{-}$(reprinted from ref. [77]. Copyright 2008 Elsevier). 
OFMMFCs can utilize the acidic, alkaline or mixed electrolyte. There is no restriction of the flow to be laminar, but the fuel utilization is largely sacrificed with higher flow rates. OFMMFCs have lower fuel utilization, because the orthogonal flow convects a portion of reactant toward electrode and remaining portion advects downstream without reacting.

\section{Stacked MMFCs}

A single-cell MMFC system is inadequate for practical and commercial applications because the output power density is insignificant. The power output of an MMFC is mainly limited by the design constraints, electrode area, fuel utilization, and ohmic and mass-transport losses. MMFCs have limited scalability because the dimensions cannot be simply increased to achieve better performance. There are increases in crossover, ohmic losses, and mass-transport losses if the anodic and cathodic reaction sites are too far from each other.

However, an MMFC system can be designed with multiple cells arranged in an array of series or parallel connections, whether in a planar or vertical configuration. This ensures higher power output, as shown in Figure 12. Multiple MMFC unit cells with different flow configurations can be housed and stacked in a single plane, as in typical PEMFCs. The volumetric power density in stacked PEMFC devices is limited by structural elements, sealing, and separators. However, the volumetric power density of stacked MMFC devices remains unaffected by structural elements as they are often fabricated using non-participating structural element materials (glass or polydimethylsiloxane (PDMS)). MMFC channels can be structured to accommodate multiple units in a single channel. MMFCs can also have a branched structure, multiple inlets, multiple streams, and fractal structure.

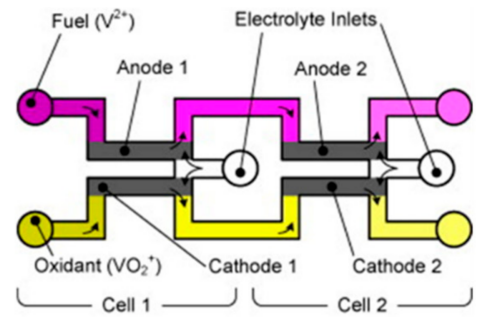

(a)

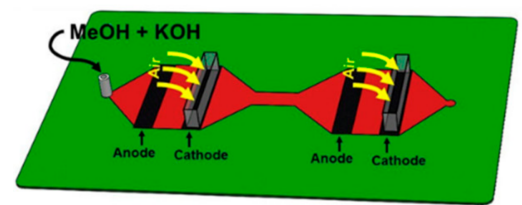

(b)

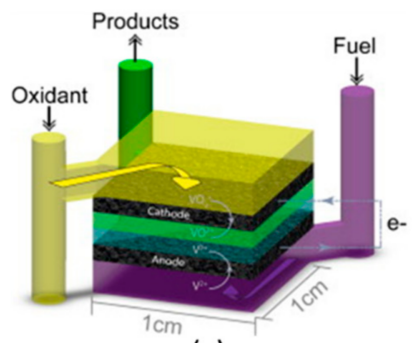

(c)
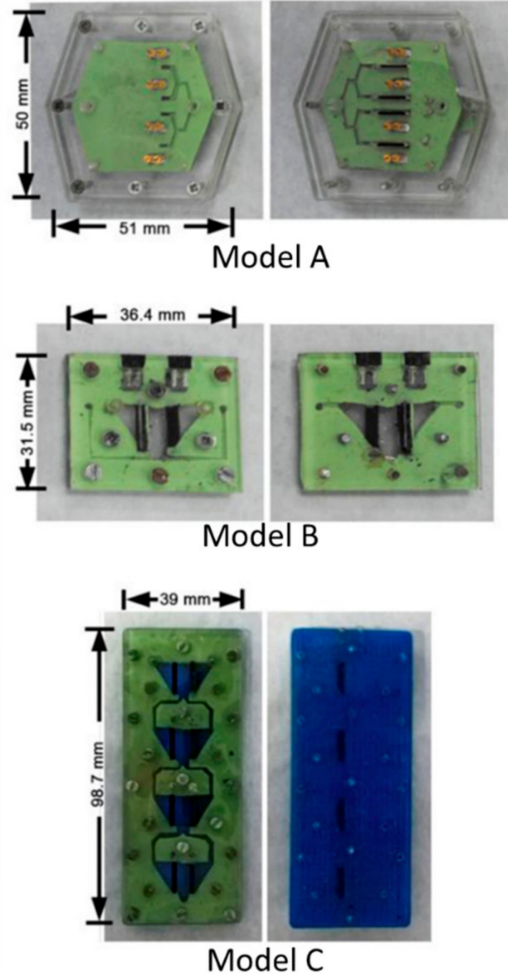

(d)

Figure 12. Evolution of MMFC stack: (a) multi-pass MMFC stack (reprinted from ref. [169]. Copyright 2011 Elsevier), (b) reactant flow in a mixed reactant microfluidic stack (reprinted from ref. [170]. Copyright 2017 Elsevier), (c) internal fluidic overview of a plate-frame flow-through MMFC stack (reprinted from ref. [119]. Copyright 2011 Elsevier), and (d) multiple design models of stacked MMFC based on fuel reuse (reprinted from ref. [171]. Copyright 2017 Elsevier). 
As an emerging technology, great research advancements have been made with MMFCs to improve their efficiency $[16,21,90,122]$, performance $[10,95,129,172]$, and application feasibility (MMFC stacking) [62,173]. Multiple MMFCs can be connected in parallel, series, or combinations of series and parallel to achieve adequate power output for commercial and practical applications [83]. Various stacking prototypes are summarized in Table 2. Salloum and Posner [169] stacked MMFCs for the first time to reuse unreacted reactants from the first cell in subsequent cells connected in parallel, as shown in Figure 12a. They used vanadium redox species as the fuel and oxidant and added an extra electrolyte stream to keep them separated. When cells were connected in parallel, the efficiency, fuel utilization, and peak power density nearly doubled.

Table 2. Performance of stacked MMFCs.

\begin{tabular}{|c|c|c|c|c|c|c|}
\hline Reference & Design Feature & OCV & Fuel/Oxidant & Current Density & Power Density & Efficiency \\
\hline & & (V) & & $\left(I_{\max }\right)$ & $\left(P_{\max }\right)$ & \\
\hline Cohen et al. [51] & 2 cells connected in parallel & 0.59 & $\mathrm{HCOOH} / \mathrm{O}_{2}$ & $1.16 \mathrm{~mA}$ & $118 \mu \mathrm{W}$ & $89 \%$ \\
\hline Kjeang et al. [78] & 12 Pair of electrode rods in parallel & 1.33 & $\mathrm{~V}^{2+} / \mathrm{VO}_{2}^{+}$ & $92 \mathrm{mAcm}^{-2}$ & $35 \mathrm{mWcm}^{-2}$ & $78 \%$ \\
\hline Salloum and Posner [169] & 2 cells connected in parallel & 1.1 & $\mathrm{~V}^{2+} / \mathrm{VO}_{2}^{+}$ & & $16.5 \mathrm{mWcm}^{-2}$ & $11 \%$ \\
\hline Moore et al. [119] & 2 cells connected in parallel & 1.4 & $\mathrm{~V}^{2+} / \mathrm{VO}_{2}^{+}$ & $15.7 \mathrm{mAcm}^{-2}$ & $5.8 \mathrm{mWcm}^{-2}$ & $66 \%$ \\
\hline Zhu et al. [90] & Electrode rods in parallel & 0.8 & $\mathrm{HCOOH} /$ Air & $118.3 \mathrm{mAcm}^{-3}$ & $21.5 \mathrm{mWcm}^{-3}$ & $87.6 \%$ \\
\hline Ho and Kjeang [132] & 2 cells connected in series & 3.0 & $\mathrm{~V}^{2+} / \mathrm{VO}_{2}^{+}$ & & $1206 \mathrm{mWcm}^{-2}$ & $64 \%$ \\
\hline Wang et al. [62] & 4 cells connected in series/parallel & 2.89 & $\mathrm{HCOOH} / \mathrm{H}_{2} \mathrm{O}_{2}$ & $1133.6 \mu \mathrm{A}$ & $265.8 \mu \mathrm{W}$ & $93 \%$ \\
\hline Wang and Leung [174] & 6 cells connected in series & 5.5 & $\mathrm{MEOH} / \mathrm{Air}$ & $80 \mathrm{mAcm}^{-2}$ & $108.7 \mathrm{mWcm}^{-2}$ & $98.4 \%$ \\
\hline Ibrahim et al. [175] & 2 cells connected in series & 2.83 & $\mathrm{~V}^{2+} / \mathrm{VO}_{2}^{+}$ & $13.5 \mathrm{~mA}$ & $9 \mathrm{~mW}$ & \\
\hline Abrego-Martínez et al. [170] & 2 cells connected in series & 0.89 & $\mathrm{MeOH} / \mathrm{KOH}$ & $25 \mathrm{mAcm}^{-2}$ & $1.42 \mathrm{mWcm}^{-2}$ & $75 \%$ \\
\hline Moreno-Zuria et al. [171] & 2 cells connected in parallel & 0.75 & $\mathrm{HCOOH} /$ Air & $345 \mathrm{mAcm}^{-2}$ & $83 \mathrm{mWcm}^{-2}$ & $95 \%$ \\
\hline Lee and Ahn [121] & 4 cells in parallel & 2.07 & $\mathrm{HCOOH} / \mathrm{KMnO}_{4}$ & $12.78 \mathrm{mAcm}^{-3}$ & $15.27 \mathrm{mWcm}^{-3}$ & $8.3 \%$ \\
\hline Wang et al. [164] & 4-cell stack Paper based & 3.8 & $\mathrm{H}_{2} / \mathrm{Air}$ & $8 \mathrm{mAcm}^{-2}$ & $12.5 \mathrm{mWcm}^{-2}$ & $90.6 \%$ \\
\hline Lee and Ahn [125] & Planar single stack in parallel & 2.0 & $\mathrm{HCOOH} / \mathrm{KMnO}_{4}$ & $26 \mu \mathrm{A}$ & $15.3 \mu \mathrm{W}$ & \\
\hline Galindo-de-la-Rosa et al. [176] & Hybrid microfluidic and enzymatic & 1.03 & $\mathrm{C}_{2} \mathrm{H}_{5} \mathrm{OH} / \mathrm{KOH}+\mathrm{O}_{2}$ & $11.42 \mathrm{mAcm}^{-2}$ & $3.154 \mathrm{mWcm}^{-2}$ & \\
\hline Escalona-Villalpando et al. [177] & 4 cells connected in series-parallel & 0.76 & Glucose $/ \mathrm{O}_{2}$ & $2007 \mu \mathrm{Acm}^{-2}$ & $579 \mu \mathrm{Wcm}^{-2}$ & $76.9 \%$ \\
\hline Lu et al. [137] & Up-scaled network & 1.0 & $\mathrm{HCOOH} / \mathrm{O}_{2}$ & $180 \mathrm{mAcm}^{-2}$ & $7 \mathrm{mWcm}^{-2}$ & $85 \%$ \\
\hline Yang et al. [178] & 4 cells connected in series & 3.0 & & $56 \mu \mathrm{Acm}^{-2}$ & $60.5 \mu \mathrm{Wcm}^{-2}$ & \\
\hline Wang and Leung [83] & 6 cells in series & 6 & Aluminum $/ \mathrm{H}_{2}+$ Air & $550 \mathrm{mAcm}^{-2}$ & $180.6 \mathrm{mWcm}^{-2}$ & \\
\hline
\end{tabular}

Cohen et al. [54] designed a two-cell MMFC stack using dissolved oxygen and formic acid as the oxidant and fuel, respectively. A maximum power of $118 \mu \mathrm{W}$ was produced, which was 2.6 times higher than that of a single cell. Ho and Kjeang [132] developed a two-cell vanadium MMFC stack with two inlet flow configurations: symmetric bilateral inlets and nonsymmetrical unilateral inlets. The former attained better performance owing to its symmetrical and uniform flow structure. The stack produced a maximum power density of $1206 \mathrm{mWcm}^{-2}$, which was 2.2 times higher than that of a single cell.

Wang et al. [62] established a four-cell MMFC stack with dissolved oxygen as the oxidant and formic acid as fuel. They examined the stack performance to find desirable conditions. Two serpentine distributers were employed to distribute the anolyte and catholyte flow evenly into four branches. This stack had 3.72 times higher peak power density when coupled in parallel, and 3.3 times higher peak power density when coupled in series than a single cell.

Abrego-Martinez et al. [170] proposed a two-cell MMFC stack that works with mixed reactants (5 $\mathrm{M}$ methanol in $\mathrm{KOH}$ ), as shown in Figure 12b. They doubled the OCV in comparison with a conventional MMFC. Lee and Ahn [125] developed an MMFC planar single stack using multiple laminar flows in a single channel. The single stacks were connected in parallel or serial. They found that such single stacks produced higher power output than arrayed structures.

Moore et al. [119] developed a plate-frame MMFC architecture with porous electrodes, as shown in Figure 12c. The architecture enabled vertical stacking by using radial flowthrough porous electrodes and produced a maximum power density of $5.8 \mathrm{mWcm}^{-2}$. Moreno-Zuria et al. [171] designed three different models of MMFC stacks that could reuse fuel, as shown in Figure 12d. They investigated MMFC stack models in series, parallel, or combinations of series and parallel. They used low-concentration fuel (0.25 M formic acid), 
and oxygen was used as the oxidant. The power density was $83 \mathrm{mWcm}^{-2}$, and the current density was $345 \mathrm{mAcm}^{-2}$ for a model connected in parallel.

Wang and Leung [83] demonstrated an MMFC stack comprising six cells connected in series and fed with aluminum. Electrolyte was reused after passing through a single cell for hydrogen formation. When operated at room temperature, the stack produced a peak power of $531 \mathrm{~mW}$ and current of $248 \mathrm{~mA}$ with an OCV of $6 \mathrm{~V}$.

\section{Fuels and Oxidants}

\subsection{Fuels}

MMFCs have been demonstrated with hydrogen [18,124,179], vanadium species $\left(\mathrm{V}^{2+}\right)[20,61,78,82,116,119,120,122,123,144,169]$ formic acid $[15,16,41,43,51-53,59,90,103,106$, 110], methanol $[34,56,57,95,107,109,110,128,174,180-182]$, hydrogen peroxide $[39,133,148$, 163,183-185], and glucose [38,48,58,98,134,135]. MMFCs have also been investigated with unconventional fuels like acetate [186], ethanol [97,187], borohydride [110,188], glycol [189], glycerol [190], urea [191], aluminum [83], ammonia [192], and formate [127]. Normally, liquid fuels exhibit significantly higher energy densities than gaseous fuels.

Figure 13 gives insight into the parameters that affect OCV. Aqueous methanol has a theoretical OCV of $1.2 \mathrm{~V}$ and an energy density of $4.69 \mathrm{kWhL}^{-1}$. MMFCs using methanol have higher power and energy densities $[56,57,181,182]$, so methanol is used extensively.

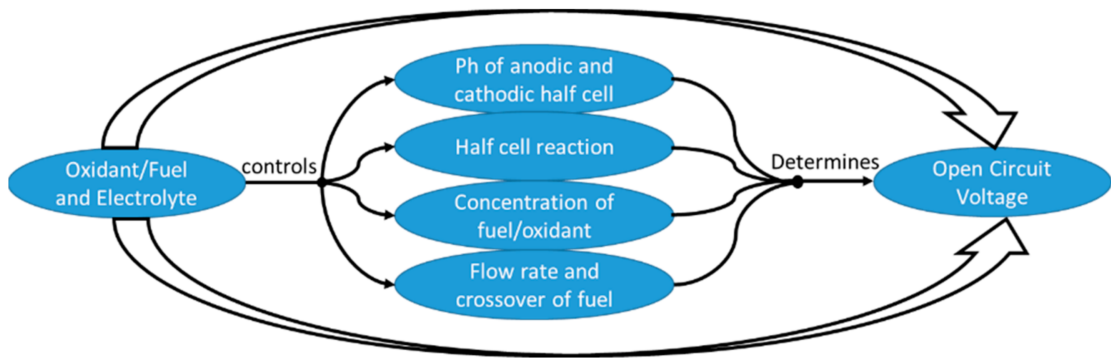

Figure 13. Concept map for the impact of oxidant, fuel, and electrolyte on the open-circuit voltage of MMFC.

Choban et al. [57] tested an MMFC running on methanol as fuel with dissolved oxygen as the oxidant. They investigated different working media (acidic, alkaline, and mixed media) and discovered that the alkaline media resulted in better reaction kinetics than acidic media. The mixed media enhanced the maximum reachable OCV considerably. The maximum achievable OCVs in acidic, alkaline, and mixed media were $0.7,0.68$, and $1.4 \mathrm{~V}$, respectively.

Reactions of methanol (fuel) and oxygen (oxidant) in acidic, alkaline, and mixed media give insight into the overall cell voltage, how it changes with the medium, and how it impacts the overall performance of MMFC:

Methanol $/ \mathrm{O}_{2}$ in acidic media

$2 \mathrm{CH}_{3} \mathrm{OH}+2 \mathrm{H}_{2} \mathrm{O} \rightarrow 2 \mathrm{CO}_{2}+12 \mathrm{H}^{+}+12 \mathrm{e}^{-} \quad$ anode $\left(\mathrm{E}^{0}=0.02 \mathrm{~V}\right)$

$12 \mathrm{H}^{+}+12 \mathrm{e}^{-}+3 \mathrm{O}_{2} \rightarrow 6 \mathrm{H}_{2} \mathrm{O}$

Methanol $/ \mathrm{O}_{2}$ in alkaline media

$2 \mathrm{CH}_{3} \mathrm{OH}+12 \mathrm{OH}^{-} \rightarrow 2 \mathrm{CO}_{2}+10 \mathrm{H}_{2} \mathrm{O}+12 \mathrm{e}^{-} \quad$ anode $\left(\mathrm{E}^{0}=-0.81 \mathrm{~V}\right)$

$3 \mathrm{O}_{2}+6 \mathrm{H}_{2} \mathrm{O}+12 \mathrm{e}^{-} \rightarrow 12 \mathrm{OH}^{-}$

Overall reaction for fully acidic or fully alkaline working media

$2 \mathrm{CH}_{3} \mathrm{OH}+3 \mathrm{O}_{2} \rightarrow 2 \mathrm{CO}_{2}+10 \mathrm{H}_{2} \mathrm{O} \quad(\Delta \mathrm{E}=1.2 \mathrm{~V})$

Methanol $/ \mathrm{O}_{2}$ in mixed media

$2 \mathrm{CH}_{3} \mathrm{OH}+2 \mathrm{H}_{2} \mathrm{O} \rightarrow 2 \mathrm{CO}_{2}+12 \mathrm{H}^{+}+12 \mathrm{e}^{-} \quad$ anode $\left(\mathrm{E}^{0}=0.02 \mathrm{~V}\right)$

$3 \mathrm{O}_{2}+6 \mathrm{H}_{2} \mathrm{O}+12 \mathrm{e}^{-} \rightarrow 12 \mathrm{OH}^{-}$

cathode $\left(\mathrm{E}^{0}=0.4 \mathrm{~V}\right)$

Overall reaction for mixed working media

$2 \mathrm{CH}_{3} \mathrm{OH}+3 \mathrm{O}_{2}+8 \mathrm{H}_{2} \mathrm{O} \rightarrow 2 \mathrm{CO}_{2}+12 \mathrm{OH}^{-}+12 \mathrm{H}^{+} \quad(\Delta \mathrm{E}=0.38 \mathrm{~V})$

However, there are numerous challenges related with methanol fuel, such as crossover and slow electrochemical kinetics, which reduce its efficiency and maximum achievable OCV in comparison with the theoretical OCV [78]. 
Aqueous formic acid has a theoretical OCV of $1.4 \mathrm{~V}$ and energy density of around $2.08 \mathrm{kWhL}^{-1}$. Choban et al. [15], Jayashree et al. [16], and Sun et al. [44] investigated MMFCs using formic acid. They found that the maximum achievable OCV using formic acid in an MMFC varies from 0.6 to $1.2 \mathrm{~V}[15,16,44]$. Montesinos et al. [43] studied a bridgeshaped microchannel and achieved an OCV of around $1.70 \mathrm{~V}$ with formic acid. There was negligible reactant crossover due to the bridge-structure, which enhanced the OCV. The OCV value for an MMFC with a bridge-structure is 10\% higher than that of similar MMFCs reported in the literature with formic acid as fuel and potassium permanganate as the oxidant.

Vanadium redox species $\left(\mathrm{V}^{2+}\right)$ is a favorable substitute for formic acid and methanol that improves the peak power density and regeneration of the fuel and oxidant for reuse in recirculation and dual-pass systems [13]. This vanadium species is favorable for MMFCs for numerous reasons: (i) it ensures higher solubility with higher redox concentrations (up to $5.4 \mathrm{M}$ ), (ii) it provides a high OCV (1.7 V), (iii) it ensures well-proportioned anodic and cathodic half-cell reactions with a better reaction rate, transport, and diffusivity characteristics, (iv) to carry out the reactions, bare carbon electrodes are sufficient without expensive metal catalysts ( $\mathrm{Pt}$ and $\mathrm{Pd}$ ), and (v) it can be regenerated easily without intricate separation arrangements.

\subsection{Oxidants}

MMFCs have been demonstrated with oxygen in aqueous form [15,18,51,56,57,98,111], vanadium species $\left(\mathrm{VO}_{2}^{+}\right)[20,61,78,120,122,123,144,169]$, hypochlorite [113], hydrogen peroxide $[39,46,59,60,92]$, and potassium permanganate $[35,43,44]$. Fundamentally, the cathodic reaction is slow in comparison with the anodic reaction. This is due to the different electrochemical kinetics of the fuel and oxidant, lower solubility of oxidants in electrolyte, and lower diffusivity. The reduction of oxygen at the cathode is passive and may require countless discrete stages and substantial reorganization of gaseous molecular oxygen. Therefore, the common activation loss occurs at the cathode.

Normally, the anodic half-cell reaction (oxidation of fuel) is six times more rapid than the cathodic half-cell reaction (reduction of oxidant) at room temperature and ambient pressure. When dissolved oxygen is used as an oxidant, low oxidant concentration slows down the electrochemical reactions at the cathode (oxidant reduction), which results in lower maximum power density and decreases the maximum achievable OCV. To eliminate the mass-transport problems involved with aqueous oxygen, alternative oxidants can be used $\left(\mathrm{H}_{2} \mathrm{O}_{2}, \mathrm{KMnO}_{4}\right.$, etc.), which have higher molecular diffusivity and are soluble at higher concentration.

Li et al. [59] used saturated oxygen as an oxidant and $0.5 \mathrm{M} \mathrm{HCOOH}$ as fuel, which were both dissolved in $0.1 \mathrm{M} \mathrm{H}_{2} \mathrm{SO}_{4}$ solution. A maximum power density of. $0.58 \mathrm{mWcm}^{-2}$ occurred due to inadequate transport of oxidant to the cathode. MMFCs with liquid oxidants have higher power outputs. Choban et al. [15] investigated an MMFC with $0.144 \mathrm{M}$ $\mathrm{KMnO}_{4}$ as the oxidant and $2.1 \mathrm{M} \mathrm{HCOOH}$ as fuel. Higher current density by an order of magnitude (from 0.8 to $8 \mathrm{mAcm}^{-2}$ ) was generated due to higher solubility of $\mathrm{KMnO}_{4}$ in aqueous media [15]. MMFCs using ambient air with an air-breathing cathode have significantly higher power and current densities $[79,109]$. MMFCs have produced reasonable performance with various fuel and oxidant combinations and flow configurations, which is similar to or even higher than that of membrane-based fuel cells. Nonetheless, their overall power production is inadequate and restricted by tiny electrode structures, micro-size channels, and working phenomena [142].

\section{Performance Comparison}

Tables 3 and 4 and Figure 14 show a quantitative performance comparison and the maximum current and power densities of various MMFCs for different flow configurations, fuel and oxidant combinations, and electrode architectures. The kinetics of an MMFC is greatly affected by the fuel type. The performance of MMFCs using formic acid, vanadium 
redox species, methanol, and hydrogen is shown in Table 4 with some unconventional fuels.

Table 3. Performance of MMFCs with different flow configurations.

\begin{tabular}{|c|c|c|c|c|c|c|}
\hline References & Flow-Configuration & Electrodes Type & OCV & $\begin{array}{l}\text { Current } \\
\text { Density }\end{array}$ & $\begin{array}{c}\text { Power } \\
\text { Density }\end{array}$ & $\begin{array}{c}\text { Fuel } \\
\text { Utilization }\end{array}$ \\
\hline & & & (V) & $\begin{array}{c}I_{\max } \\
\left(\mathrm{mAcm}^{-2}\right)\end{array}$ & $\underset{\left(\mathrm{mWcm}^{-2}\right)}{\mathbf{P}_{\max }}$ & \\
\hline Choban et al. [57] & Side-by-side streaming & Flow-over & 1.40 & 40 & 12 & $10 \%$ \\
\hline Montesinos et al. [43] & Side-by-side streaming & Flow-over & 1.35 & & 49 & $15.4 \%$ \\
\hline Jayashree et al. [16] & Vertical-layered streaming & Air-breathing & 0.92 & 130 & 26 & $8 \%$ \\
\hline Ortega et al. [100] & Vertical-layered streaming & Flow-through anode air-breathing cathode & 0.9 & 490 & 100 & \\
\hline Shaegh et al. [103] & Vertical-layered streaming & Air-breathing with fuel reservoir & 0.8 & 140 & 29 & $22 \%$ \\
\hline Kjeang et al. [82] & Vertical-layered streaming & Flow-through & 1.55 & 326 & 131 & $100 \%$ \\
\hline Kjeang et al. [113] & Vertical-layered streaming & Flow-through & 1.42 & 230 & 52 & $100 \%$ \\
\hline Goulet et al. [112] & Vertical-layered streaming & Flow-through & 1.5 & 4600 & 2010 & $90 \%$ \\
\hline Lee and Ahn [121] & Multi-stream & Flow-through (single cell) & 1.04 & $\begin{array}{c}15.25 \\
\mathrm{mAcm}^{-3}\end{array}$ & $\begin{array}{l}7.42 \\
\mathrm{mWcm}^{-3}\end{array}$ & \\
\hline Sun et al. [44] & Multi-stream & Flow-over & 1.0 & 2.6 & 0.7 & \\
\hline Jayashree et al. [124] & Multi-stream & Flow-through & 0.94 & 960 & 191 & \\
\hline Kwok et al. [128] & Multi-stream & Air-breathing & 0.95 & 450 & 210 & \\
\hline Lu et al. [129] & Multi-stream & Air-breathing & 1.89 & 3600 & 1300 & \\
\hline Ibrahim et al. [130] & Dual Pass & Flow-through & 1.554 & 1000 & 750 & $52 \%$ \\
\hline Ho and Kjeang [132] & Dual Pass & Flow-through & 3 & 2000 & 1206 & $64 \%$ \\
\hline Goulet et al. [122] & Dual Pass & Flow-through & 1.53 & $5.6 \mathrm{~mA}$ & & \\
\hline Esquivel et al. [155] & Lateral-flow & & & 276 & 103.2 & \\
\hline Arun et al. [161] & Lateral-flow & & 0.33 & 650 & 32 & \\
\hline Wu et al. [127] & Lateral-flow multi-stream & Flow-through & 0.91 & 111.2 & 19.9 & $20.7 \%$ \\
\hline Zhou et al. [101] & Lateral-flow multi-stream & Flow-over anode air-breathing cathode & 1.04 & $325 \mathrm{mAcm}^{-3}$ & $\begin{array}{c}119.3 \\
\mathrm{~mW} \mathrm{~cm}^{-3}\end{array}$ & $6.5 \%$ \\
\hline Salloum and Posner [61] & Counter-flow & Flow-through & 1.21 & 19 & 5 & $24.9 \%$ \\
\hline Lu et al. [137] & Counter-flow & Flow-through & 1.0 & 180 & 7 & \\
\hline Xuan et al. [63] & Counter-flow & Flow-over & 0.8 & 181 & 35 & \\
\hline Salloum et al. [35] & Radial flow & Flow-through & 1.2 & 5 & 2.8 & $58 \%$ \\
\hline Li et al. [144] & Radial flow & Flow-through & 1.51 & & $0.35 \mathrm{~mW}$ & $53.33 \%$ \\
\hline Hayes et al. [77] & Orthogonal flow & Flow-through & 0.9 & & 46 & $42 \%$ \\
\hline
\end{tabular}

Table 4. Performance of MMFCs with different reactants.

\begin{tabular}{|c|c|c|c|c|c|c|}
\hline References & Fuel/Oxidant & Electrode Type & Electrolyte & OCV & $\begin{array}{l}\text { Current } \\
\text { Density }\end{array}$ & $\begin{array}{l}\text { Power } \\
\text { Density }\end{array}$ \\
\hline & & & & (V) & $\begin{array}{c}\mathrm{I}_{\max } \\
\left(\mathrm{mAcm}^{-2}\right)\end{array}$ & $\begin{array}{c}\mathbf{P}_{\max } \\
\left(\mathrm{mAcm}^{-2}\right)\end{array}$ \\
\hline Jayashree et al. [16] & $\mathrm{HCOOH} / \mathrm{Air}$ & Air-breathing & $0.5 \mathrm{M} \mathrm{H}_{2} \mathrm{SO}_{4}$ & 0.92 & 130 & 26 \\
\hline Ortega et al. [100] & $\mathrm{HCOOH} /$ Air & Flow-through anode air-breathing cathode & $0.5 \mathrm{M} \mathrm{H}_{2} \mathrm{SO}_{4}$ & 0.9 & 490 & 100 \\
\hline Shaegh et al. [103] & $\mathrm{HCOOH} /$ Air & Air-breathing with fuel reservoir & $2 \mathrm{M} \mathrm{H}_{2} \mathrm{SO}_{4}$ & 0.8 & 140 & 29 \\
\hline Shaegh et al. [118] & $\mathrm{HCOOH} / \mathrm{Air}$ & Air-breathing cathode and flow through anode & $0.5 \mathrm{M} \mathrm{H}_{2} \mathrm{SO}_{4}$ & 0.9 & 120 & 26.5 \\
\hline Brushett et al. [110] & $\mathrm{HCOOH} /$ Air & Air-breathing & $0.5 \mathrm{M} \mathrm{H}_{2} \mathrm{SO}_{4}$ & & 130 & 26 \\
\hline Kjeang et al. [113] & $\mathrm{HCOOH} / \mathrm{NaOCl}$ & Flow-through & $2.8 \mathrm{M} \mathrm{NaOH}$ & 1.42 & 230 & 52 \\
\hline Choban et al. [57] & $\mathrm{CH}_{3} \mathrm{OH} / \mathrm{O}_{2}$ & Flow-over & & 1.40 & 40 & 12 \\
\hline Whipple et al. [107] & $\mathrm{CH}_{3} \mathrm{OH} / \mathrm{Air}$ & Air-breathing & $0.5 \mathrm{M} \mathrm{H}_{2} \mathrm{SO}_{4}$ & 0.7 & 62 & 4 \\
\hline Jayashree et al. [109] & $\mathrm{CH}_{3} \mathrm{OH} / \mathrm{KOH}$ & Air-breathing & $0.5 \mathrm{M} \mathrm{H}_{2} \mathrm{SO}_{4}$ & 1.05 & 120 & 17 \\
\hline Thorson et al. [95] & $\mathrm{CH}_{3} \mathrm{OH} / \mathrm{Air}$ & Electrode arrangement in Air-breathing MFC & $1 \mathrm{M} \mathrm{KOH}$ & 0.7 & 121 & 24.9 \\
\hline Hollinger et al. [180] & $\mathrm{CH}_{3} \mathrm{OH} / \mathrm{Air}$ & Air-breathing & $1 \mathrm{M} \mathrm{H}_{2} \mathrm{SO}_{4}$ & 0.64 & 655 & 90 \\
\hline Ferrigno et al. [13] & $\mathrm{V}^{2+} / \mathrm{VO}_{2}^{+}$ & Flow-over & $0.25 \mathrm{M} \mathrm{H}_{2} \mathrm{SO}_{4}$ & & & 38 \\
\hline Lee et al. [115] & $\mathrm{V}^{2+} / \mathrm{VO}_{2}^{+}$ & Nano-foam flow-through & $1.8 \mathrm{M} \mathrm{H}_{2} \mathrm{SO}_{4}$ & 1.5 & 80 & \\
\hline Lee et al. [116] & $\mathrm{V}^{2+} / \mathrm{VO}_{2}^{+}$ & Chip embedded flow-through & $1.8 \mathrm{M} \mathrm{H}_{2} \mathrm{SO}_{4}$ & 1.5 & & 93 \\
\hline Kjeang et al. [82] & $\mathrm{V}^{2+} / \mathrm{VO}_{2}^{+}$ & Flow-through & $1 \mathrm{M} \mathrm{H}_{2} \mathrm{SO}_{4}$ & 1.55 & 326 & 131 \\
\hline Ibrahim et al. [130] & $\mathrm{V}^{2+} / \mathrm{VO}_{2}^{+}$ & Dual Pass Flow-through & $1 \mathrm{M} \mathrm{H}_{2} \mathrm{SO}_{4}$ & 1.55 & 1000 & 750 \\
\hline Ho and Kjeang [132] & $\mathrm{V}^{2+} / \mathrm{VO}_{2}^{+}$ & Dual Pass Flow-through & $1 \mathrm{M} \mathrm{H}_{2} \mathrm{SO}_{4}$ & 3 & 2000 & 1206 \\
\hline Goulet et al. [112] & $\mathrm{V}^{2+} / \mathrm{VO}_{2}^{+}$ & Flow-through & $4 \mathrm{M} \mathrm{H}_{2} \mathrm{SO}_{4}$ & 1.5 & 4600 & 2010 \\
\hline Hayes et al. [77] & $\mathrm{H}_{2} / \mathrm{O}_{2}$ & Flow-through & $1.8 \mathrm{M} \mathrm{H}_{2} \mathrm{SO}_{4}$ & 0.9 & & 46 \\
\hline Brushett et al. [179] & $\mathrm{H}_{2} / \mathrm{O}_{2}$ & Flow-through & $3 \mathrm{M} \mathrm{KOH}$ & 1 & 600 & 108 \\
\hline Jayashree et al. [124] & $\mathrm{H}_{2} / \mathrm{O}_{2}$ & Flow-through & $2 \mathrm{M} \mathrm{H}_{2} \mathrm{SO}_{4}$ & 0.94 & & 191 \\
\hline Lu et al. [129] & $\mathrm{H}_{2} / \mathrm{O}_{2}$ & Air-breathing & $3 \mathrm{M} \mathrm{H}_{2} \mathrm{SO}_{4} \& 3 \mathrm{M} \mathrm{KOH}$ & 1.89 & 3600 & 1300 \\
\hline Braff et al. [193] & $\mathrm{H}_{2} / \mathrm{Br}_{2}$ & Flow-over and H2-breathing & $1 \mathrm{M} \mathrm{HBr}$ & 0.95 & & 795 \\
\hline Martins et al. [194] & Glycerorl/bleach & Flow-through & $1 \mathrm{M} \mathrm{H}_{2} \mathrm{SO}_{4} \& 2 \mathrm{M} \mathrm{KOH}$ & 2 & 638 & 315 \\
\hline Mota et al. [188] & $\mathrm{NaBH}_{4} / \mathrm{CAN}$ & Chaotic flow-over & & 2.2 & & 270 \\
\hline
\end{tabular}




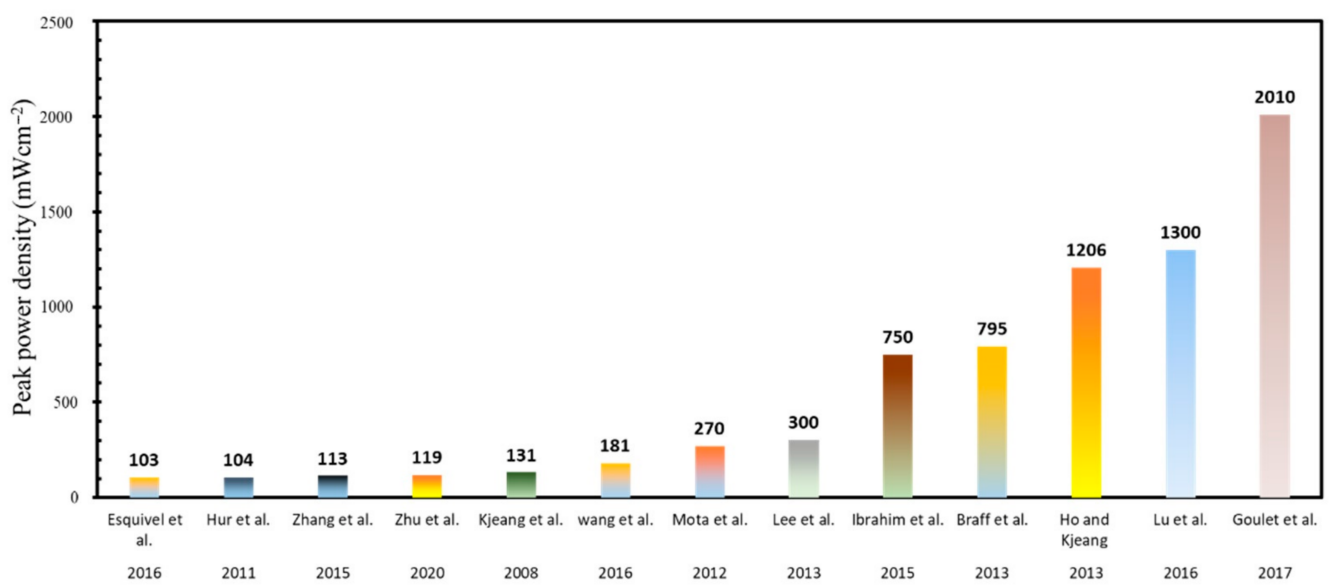

Figure 14. Comparison of power densities among different flow configurations.

Table 3 shows that the maximum power density varies from 1 to $50 \mathrm{mWcm}^{-2}$ for MMFCs with different flow configurations and flow-over electrodes. The maximum fuel utilization is only $15 \%$ when using flow-over electrodes. The flow-through designs produce a maximum power density of up to $1200 \mathrm{mWcm}^{-2}$, and some of them achieve $100 \%$ fuel utilization. The electrodes with flow-over architecture results in lower performance due to a thicker depletion zone over the electrodes and lower oxidant concentration around the cathode. This results in significant mass-transport losses, and lower fuel utilization. The electrodes with flow-through architectures performs better owing to the enrichment of catalytic reaction sites via pores and effective three-dimensional electrode structures with active replenishment of reactants over the catalytic sites.

An air-breathing cathode coupled with a flow-over or flow-through anode can also enhance the maximum power density. MMFCs with air-breathing cathodes can produce a maximum power density of 30 to $120 \mathrm{mWcm}^{-2}$. The air-breathing cathode architecture has not been investigated for complex flow configurations (dual-pass, recirculation, multi-stream, radial-flow, and orthogonal-flow configurations). Fabricating air-breathing electrodes with these flow configurations is complicated in comparison with flow-over electrodes. The reason for the high performance of MMFCs using air-breathing cathode is the efficient transport of oxygen to the cathode directly from ambient air. The constant concentration of oxygen in the catholyte enhances the power density.

\section{Challenges and Prospective Studies}

The articles published since 2002 have cemented the foundation for the commercialization of MMFCs. Recently, extensive accomplishments have been made in the areas of unconventional reactants $[113,191,193,195,196]$, catalysts [197-201], electrode configurations [92,119,188,202,203], electrode materials [107,117,190,204-206], and MMFC architectures $[54,61,78,207-210]$. Key challenges and major issues must be addressed to benefit from the advantages of MMFCs as a long-lasting power source. Table 5 gives insight into the development of future MMFCs with higher power density and fuel utilization.

Table 5. Insights into next-generation MMFC components and flow configurations.

Flow configuration/Electrode Architecture/Technique

Counter-flow/Radial-flow

Multi-stream (additional electrolytic stream)

Dual Pass/Recirculation

Flow-through anode

Air-breathing cathode

Fuel/Oxidant (Vanadium redox/Aluminum)

\section{Attributed Feature}

Minimize redundant convective mixing

Minimize cross-over issues

To add up OCV and enhance maximum power density Enhance fuel utilization

Ensures uniform oxidant concentration

To have higher theoretical OCV

To enhance overall OCV and maximize power density 
The performance of MMFCs is primarily restricted by the slower mass-transportation to the electrodes and lower oxidant's concentration and solubility in the cathodic reaction $[33,56]$. The MMFC with air-breathing cathode lets oxygen transport from the ambient air continuously, which enhances the diffusivity and provides uniform concentration in comparison with dissolved oxygen provided in flow-over or flow-through cathode architecture. However, the air-breathing architecture decreases the probability of scaling up by stacking units of MMFCs [78]. However, multi-stream CLFMMFCs can be investigated by employing air-breathing electrodes at both ends and placing flow-through electrodes with selective catalysis to avoid fuel reacting at cathode and causing mixed potential.

In counter-flow MMFCs, the fuel and oxidant are kept isolated by inserting an electrolytic stream during their residence time in the fuel cell, do not blend or fuse diffusively, and they are collected distinctly. Thus, the reactants can be recirculated to enhance the fuel utilization and power density. Sequential RFMMFC configurations remove linear diffusion along the length. Nevertheless, there is a possibility that in the sequential RFMMFCs, fuel may crossover and react at cathode causing mixed potential. Salloum et al. [62] proposed careful tuning of flow rate and selective catalysis to avoid fuel reacting at cathode. However, a sequential RFMMFC configuration with an additional electrolytic stream (multi-stream) can be studied prospectively, the fuel and oxidant pass through porous disc-shaped electrodes and avoid forming a diffusive interfacial zone due to the electrolytic stream, which ensures minimum fuel crossover with significant fuel utilization. Furthermore, the fuel and oxidant streams can be collected distinctly at the outlet and recirculated. A multistream OFMMFC can be developed by inserting multiple orthogonal electrolytic streams to enhance the performance of the fuel cell.

The highest power density to date in MMFCs was achieved by using vanadium redox species $\left(\mathrm{V}^{2+} / \mathrm{VO}_{2}^{+}\right)$as the fuel and oxidant. The $\left(\mathrm{V}^{2+} / \mathrm{VO}_{2}^{+}\right)$couple ensures rapid diffusion and species transport, as well as uniform reaction rates. The OCV $(1.5 \mathrm{~V})$ achieved by the vanadium redox couple is higher than those of other fuel and oxidant combinations (e.g., formic acid coupled with different oxidants). Additionally, the vanadium redox species can react with bare carbon electrodes without any catalyst. Among unconventional fuels, $\mathrm{Al}$ is abundantly available, light-weight, cost-efficient, eco-friendly, and recyclable, which makes it a very appropriate choice as an "indirect fuel" in hydrogen-based MMFCs. Additionally, as an alkaline catalyst, $\mathrm{Al}$ reacts spontaneously and vigorously, resulting in excess $\mathrm{H}_{2}$ for MMFC operation [83]. Thus, it can be effectively used in next-generation MMFCs.

The major factors that limit the performance of MMFCs can be solved by using a suitable flow configuration with an improved electrode architecture that can be used in stacked units of MMFCs. The residence time and removal of depleted region over the surface of electrodes can be resolved by placing lateral paper-based strips over a selective area of electrode to advect the depletion region downstream. Commercialization of MMFCs can be made possible by: (i) mushrooming performance of MMFCs (e.g., by stacking multiple unit MMFCs), (ii) minimizing crossover issues (e.g., by using a counterflow or radial-flow configuration with an additional electrolytic stream), (iii) enhancing fuel utilization (e.g., by using flow-through anodes and dual pass/recirculation), (iv) minimizing mass-transport losses (e.g., by implementing air-breathing cathodes), and (v) implementing a fuel-oxidant couple with better OCV and electrochemical kinetics.

\section{Applications}

Although MMFCs have enormous potential, their applications as a power source are delimited due to the lower performance linked with two key limitations: (i) the fuel and oxidant streams are laminar, which occurs in microchannels, and (ii) intrinsic design constrictions. The power output from a single MMFC is insufficient for commercial applications. Hence, numerous MMFC units are stacked in series or parallel with any of the aforementioned reactants' flow configurations to reach sufficient power for practical applicability. MMFCs can be combined directly with lab-on-chip devices (on-chip applications). 
Devices employed for biological and environmental sampling, motion sensors, wireless sensors, and detection, can be directly powered by MMFCs.

The on-chip applications may have low- or high-power demands [155]. To fulfil the energy requirements of both power modes in such devices, an MMFC can energize a secondary battery by functioning continuously. Abrego-Martinez et al. [170] designed a MMFC stack with two cells that can produce the power to run low-power applications, such as micro analytical systems, blood diagnostics, DNA analysis devices, and LEDs [211]. Gurrola et al. [212] developed a membraneless nano-fluidic fuel cell using fiberglass as substrate and electrodes with flow-through architecture. They coupled their power source with a microelectronic interface (Figure 15a) and analyzed it for functioning lower power devices, such as LEDs.

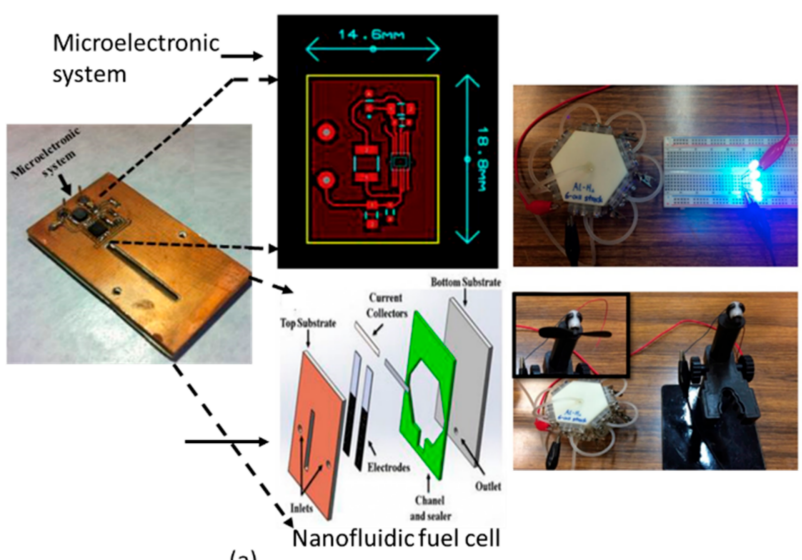

(a)

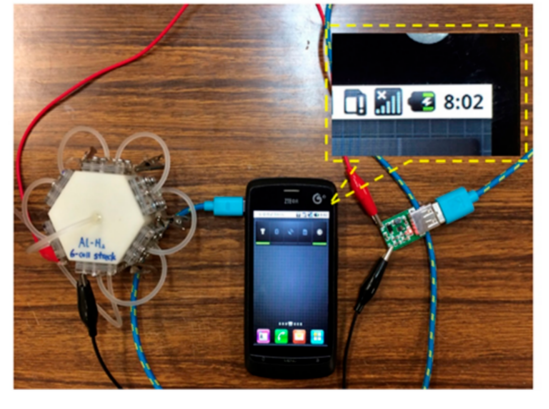

(b)

Figure 15. Applications of MMFCs: (a) membraneless nanofluidic fuel cell assembly with microelectronic system for low-power applications (reprinted from ref. [189]. Copyright 2016 Elsevier) and (b) an aluminum feed MMFC stack demonstrated for several practical applications (reprinted from ref. [149]. Copyright 2016 Elsevier).

Wang and Leung [83] designed a novel MMFC stack fed with aluminum. They illustrated the practical applicability of the stack by charging a cell phone, driving an electric fan, and lighting LEDs, as shown in Figure 15b. LFMMFCs are being extensively used commercially for micro devices, such as commercial glucometers $[67,68]$ and selfpowered sensors [71]. They are applied to efficiently separate analytes by a paper-based channel $[72,75]$ and to detect lake water, human serum samples [69], and pentachlorophenol in real samples [74]. They also have point-of-care applications [155]. Dector et al. [165] developed a paper-based LFMMFC that uses blood as fuel to investigate HIV AIDS.

The practical applicability of MMFCs and commercialization are dependent on the improvement in the performance (i.e., peak power density and fuel utilization) at low flow rates of reactant streams in a unit of MMFC, which enhances the maximum reachable power density when unit cells are stacked together. To accomplish higher power density, reactants transportation and electrochemical kinetics should be upgraded. For lower flow rates of fuel and oxidant, crossover turns out to be substantial, resulting in a thicker mixing region. The electrodes with flow-through architecture in combination with new flow configurations could provide a way to improved fuel utilization and power density. Additionally, by enhancing the fuel utilization, the fuel concentration at the interface of the co-laminar flow would be decreased, and fuel crossover would be alleviated. The electrodes with better architecture and design can be constructed using microfabrication techniques to increase the rate of the electrochemical reactions by enhancing the reactive surface area. However, this process could increase the total fabrication cost.

MMFCs are an attractive alternative due to their functioning at room temperature, lower manufacturing cost, and flexible material selection. However, there are still several complications affecting commercialization, i.e., obligatory electric pumping, complex water 
system, lower portability owing to stable workstation, and stacking complications. To resolve these issues, great efforts have been made to boost the performance by (i) improving microchannel design, (ii) improving electrode architecture by continuous development of fuel-tolerant cathodes for different fuels, (iii) replacing electric pumping with passive pumping, and (iv) enhancing MMFC stability in portable applications employing an extra porous separator at fuel-oxidant interface. The channel thickness can be reduced to reduce ohmic resistance to the passage of ions. As for real applications, currently, the paper-based MMFCs are being employed in market for biosensors and point-of-care devices.

\section{Conclusions}

This review article discussed key changes in the evolution of MMFCs, which use a variety of flow configurations and electrode arrangements. Far-reaching developments have been accomplished in the design and performance of MMFCs. Nonetheless, commercialization for practical usage of MMFCs is a milestone that is yet to be achieved. But there are immense prospects for research and advancement in this field in the coming years. High performance can be attained by careful modifications of the microchannel structure, flow configuration, and electrode architecture while keeping in mind the transport of reactants to reaction sites (electrode surfaces) and the resulting electrochemical kinetics.

Among the various flow configurations, a combination of radial-flow and counter-flow configurations for dual-pass MMFCs with porous or air-breathing electrodes could be a vital option for practical applications. Commercialization of MMFCs inevitably requires stacking of single cells using different flow configurations for scaling up of the performance. Thus, MMFCs require a flow channel configuration that ensures effective and space-efficient interconnection of the unit cells for stacking. This review article could help researchers to resolve the challenges in MMFCs' commercialization.

Author Contributions: M.T.: conceptualization, writing-original draft, K.-Y.K.: writing-review and editing, supervision, funding acquisition. Both authors have read and agreed to the published version of the manuscript.

Funding: This work was supported by the National Research Foundation of Korea (NRF) grant funded by the Korean government (MSIT) (No. 2019R1A2C1007657).

Institutional Review Board Statement: Not applicable.

Informed Consent Statement: Not applicable.

Data Availability Statement: Not applicable.

Acknowledgments: The authors thank Eun Su Lim for the assistance in preparing the manuscript.

Conflicts of Interest: The authors declare no conflict of interest.

\section{References}

1. Rugolo, J.; Aziz, M.J. Electricity storage for intermittent renewable sources. Energy Environ. Sci. 2012, 5, 7151-7160. [CrossRef]

2. Soloveichik, G.L. Battery Technologies for Large-Scale Stationary Energy Storage. Annu. Rev. Chem. Biomol. Eng. 2011, 2, 503-527. [CrossRef] [PubMed]

3. Kosek, J.A.; Laconti, A.B. Advanced hydrogen electrode for a hydrogen-bromine battery. J. Power Sources 1988, 22, 293-300. [CrossRef]

4. Liu, Q.; Shinkle, A.A.; Li, Y.; Monroe, C.W.; Thompson, L.T.; Sleightholme, A.E.S. Non-aqueous chromium acetylacetonate electrolyte for redox flow batteries. Electrochem. Commun. 2010, 12, 1634-1637. [CrossRef]

5. Duduta, M.; Ho, B.; Wood, V.C.; Limthongkul, P.; Brunini, V.E.; Carter, W.C.; Chiang, Y.M. Semi-solid lithium rechargeable flow battery. Adv. Energy Mater. 2011, 1, 511-516. [CrossRef]

6. Kurzweil, P.; Garche, J. Overview of batteries for future automobiles. In Lead-Acid Batteries for Future Automobiles; Elsevier Inc.: Amsterdam, The Netherlands, 2017; pp. 27-96, ISBN 9780444637031.

7. Dyer, C.K. Fuel cells for portable applications. J. Power Sources 2002, 106, 31-34. [CrossRef]

8. Kundu, A.; Jang, J.; Gil, J.; Jung, C.; Lee, H.R.; Kim, S.H.; Ku, B.; Oh, Y.S. Micro-fuel cells—Current development and applications. J. Power Sources 2007, 170. [CrossRef]

9. Bloch, D. Miniature fuel cells for portable applications. In Technologies and Devices; Low Power Electronic Design; CRC Press: Boca Raton, FL, USA, 2005; Volume 106, pp. 44-1-44-20. [CrossRef] 
10. Wang, Y.; Leung, D.Y.C.; Xuan, J.; Wang, H. A review on unitized regenerative fuel cell technologies, part-A: Unitized regenerative proton exchange membrane fuel cells. Renew. Sustain. Energy Rev. 2016, 65, 961-977. [CrossRef]

11. Larminie, J.; Dicks, A. Fuel Cell Systems Explained, 2nd ed.; John Wiley \& Sons Ltd.: Chichester, UK, 2003.

12. Kelley, S.C.; Deluga, G.A.; Smyrl, W.H. Miniature methanol/air polymer electrolyte fuel cell. Electrochem. Solid State Lett. 2000, 3, 407-409. [CrossRef]

13. Ferrigno, R.; Stroock, A.D.; Clark, T.D.; Mayer, M.; Whitesides, G.M. Membraneless vanadium redox fuel cell using laminar flow. J. Am. Chem. Soc. 2002, 124, 12930-12931. [CrossRef]

14. Wu, J.; Yuan, X.Z.; Martin, J.J.; Wang, H.; Zhang, J.; Shen, J.; Wu, S.; Merida, W. A review of PEM fuel cell durability: Degradation mechanisms and mitigation strategies. J. Power Sources 2008, 184, 104-119. [CrossRef]

15. Choban, E.R.; Markoski, L.J.; Wieckowski, A.; Kenis, P.J.A. Microfluidic fuel cell based on laminar flow. J. Power Sources 2004, 128, 54-60. [CrossRef]

16. Jayashree, R.S.; Gancs, L.; Choban, E.R.; Primak, A.; Natarajan, D.; Markoski, L.J.; Kenis, P.J.A. Air-breathing laminar low-based microfluidic fuel cell. J. Am. Chem. Soc. 2005, 127, 16758-16759. [CrossRef]

17. Mousavi Shaegh, S.A.; Nguyen, N.T.; Chan, S.H. A review on membraneless laminar flow-based fuel cells. Int. J. Hydrogen Energy 2011, 36, 5675-5694. [CrossRef]

18. Cohen, J.L.; Volpe, D.J.; Westly, D.A.; Pechenik, A.; Abruña, H.D. A dual electrolyte H2/O2 planar membraneless microchannel fuel cell system with open circuit potentials in excess of $1.4 \mathrm{~V}$. Langmuir 2005, 21, 3544-3550. [CrossRef]

19. Chen, F.; Chang, M.H.; Lin, M.K. Analysis of membraneless formic acid microfuel cell using a planar microchannel. Electrochim. Acta 2007, 52, 2506-2514. [CrossRef]

20. Kjeang, E.; Proctor, B.T.; Brolo, A.G.; Harrington, D.A.; Djilali, N.; Sinton, D. High-performance microfluidic vanadium redox fuel cell. Electrochim. Acta 2007, 52, 4942-4946. [CrossRef]

21. Goulet, M.A.; Kjeang, E. Co-laminar flow cells for electrochemical energy conversion. J. Power Sources 2014, $260,186-196$. [CrossRef]

22. Tanveer, M.; Kim, K.-Y. Effects of geometric configuration of the channel and electrodes on the performance of a membraneless micro-fuel cell. Energy Convers. Manag. 2017, 136. [CrossRef]

23. Ho, B.; Kjeang, E. Microfluidic fuel cell systems. Cent. Eur. J. Eng. 2011, 1. [CrossRef]

24. Kjeang, E.; Djilali, N.; Sinton, D. Microfluidic fuel cells: A review. J. Power Sources 2009, 186, 353-369. [CrossRef]

25. Goel, S. From waste to watts in micro-devices: Review on development of Membraned and Membraneless Microfluidic Microbial Fuel Cell. Appl. Mater. Today 2018, 11, 270-279. [CrossRef]

26. Hristovski, K.D.; Dhanasekaran, B.; Tibaquirá, J.E.; Posner, J.D.; Westerhoff, P.K. Producing drinking water from hydrogen fuel cells. J. Water Supply Res. Technol. AQUA 2009, 58, 327-335. [CrossRef]

27. Tanveer, M.; Kim, K. A membraneless microfluidic fuel cell with a hollow flow channel and porous flow-through electrodes. Int. J. Energy Res. 2021, 45, 8536-8550. [CrossRef]

28. Tanveer, M.; Lim, E.S.; Kim, K.Y. Effects of channel geometry and electrode architecture on reactant transportation in membraneless microfluidic fuel cells: A review. Fuel 2021, 298, 120818. [CrossRef]

29. Hanapi, I.H.; Kamarudin, S.K.; Zainoodin, A.M.; Hasran, U.A. Membrane-less micro fuel cell system design and performance: An overview. Int. J. Energy Res. 2019, 43, 8956-8972. [CrossRef]

30. Novak, J.; Gowin, D. Learning How to Learn; Cambridge University Press: Cambridge, UK, 1984.

31. Bird, R.B. Transport phenomena. Appl. Mech. Rev. 2002, 55, R1-R4. [CrossRef]

32. Bazylak, A.; Sinton, D.; Djilali, N. Improved fuel utilization in microfluidic fuel cells: A computational study. J. Power Sources 2005, 143, 57-66. [CrossRef]

33. Chang, M.H.; Chen, F.; Fang, N.S. Analysis of membraneless fuel cell using laminar flow in a Y-shaped microchannel. J. Power Sources 2006, 159, 810-816. [CrossRef]

34. Hollinger, A.S.; Kenis, P.J.A. Manufacturing all-polymer laminar flow-based fuel cells. J. Power Sources 2013, $240,486-493$. [CrossRef]

35. Salloum, K.S.; Hayes, J.R.; Friesen, C.A.; Posner, J.D. Sequential flow membraneless microfluidic fuel cell with porous electrodes. J. Power Sources 2008, 180, 243-252. [CrossRef]

36. Tominaka, S.; Obata, H.; Osaka, T. On-chip direct methanol fuel cells of a monolithic design: Consideration on validity of active-type system. Energy Environ. Sci. 2009, 2, 845-848. [CrossRef]

37. Arun, R.K.; Bekele, W.; Ghatak, A. Self oscillating potential generated in patterned micro-fluidic fuel cell. Electrochim. Acta 2013, 87, 489-496. [CrossRef]

38. Cuevas-Muñiz, F.M.; Guerra-Balcázar, M.; Castaneda, F.; Ledesma-García, J.; Arriaga, L.G. Performance of Au and AuAg nanoparticles supported on Vulcan in a glucose laminar membraneless microfuel cell. J. Power Sources 2011, 196, 5853-5857. [CrossRef]

39. Hasegawa, S.; Shimotani, K.; Kishi, K.; Watanabe, H. Electricity generation from decomposition of hydrogen peroxide. Electrochem. Solid State Lett. 2005, 8, A119. [CrossRef]

40. Lim, K.G.; Palmore, G.T.R. Microfluidic biofuel cells: The influence of electrode diffusion layer on performance. Biosens. Bioelectron. 2007, 22, 941-947. [CrossRef] 
41. Morales-Acosta, D.; Morales-Acosta, M.D.; Godinez, L.A.; Álvarez-Contreras, L.; Duron-Torres, S.M.; Ledesma-García, J.; Arriaga, L.G. PdCo supported on multiwalled carbon nanotubes as an anode catalyst in a microfluidic formic acid fuel cell. J. Power Sources 2011, 196, 9270-9275. [CrossRef]

42. Shyu, J.C.; Wei, C.S.; Lee, C.J.; Wang, C.C. Investigation of bubble effect in microfluidic fuel cells by a simplified microfluidic reactor. Appl. Therm. Eng. 2010, 30, 1863-1871. [CrossRef]

43. López-Montesinos, P.O.; Yossakda, N.; Schmidt, A.; Brushett, F.R.; Pelton, W.E.; Kenis, P.J.A. Design, fabrication, and characterization of a planar, silicon-based, monolithically integrated micro laminar flow fuel cell with a bridge-shaped microchannel cross-section. J. Power Sources 2011, 196, 4638-4645. [CrossRef]

44. Sun, M.H.; Velve Casquillas, G.; Guo, S.S.; Shi, J.; Ji, H.; Ouyang, Q.; Chen, Y. Characterization of microfluidic fuel cell based on multiple laminar flow. Microelectron. Eng. 2007, 84, 1182-1185. [CrossRef]

45. Shyu, J.C.; Huang, C.L. Characterization of bubble formation in microfluidic fuel cells employing hydrogen peroxide. J. Power Sources 2011, 196, 3233-3238. [CrossRef]

46. Kjeang, E.; Brolo, A.G.; Harrington, D.A.; Djilali, N.; Sinton, D. Hydrogen Peroxide as an Oxidant for Microfluidic Fuel Cells. J. Electrochem. Soc. 2007, 154, B1220-B1226. [CrossRef]

47. Wang, H.Y.; Su, J.Y. Membraneless microfluidic microbial fuel cell for rapid detection of electrochemical activity of microorganism. Bioresour. Technol. 2013, 145, 271-274. [CrossRef]

48. Zebda, A.; Renaud, L.; Cretin, M.; Pichot, F.; Innocent, C.; Ferrigno, R.; Tingry, S. A microfluidic glucose biofuel cell to generate micropower from enzymes at ambient temperature. Electrochem. Commun. 2009, 11, 592-595. [CrossRef]

49. Zebda, A.; Renaud, L.; Cretin, M.; Innocent, C.; Ferrigno, R.; Tingry, S. Membraneless microchannel glucose biofuel cell with improved electrical performances. Sens. Actuators B Chem. 2010, 149, 44-50. [CrossRef]

50. Li, Z.; Zhang, Y.; LeDuc, P.R.; Gregory, K.B. Microbial electricity generation via microfluidic flow control. Biotechnol. Bioeng. 2011, 108, 2061-2069. [CrossRef] [PubMed]

51. Cohen, J.L.; Westly, D.A.; Pechenik, A.; Abruña, H.D. Fabrication and preliminary testing of a planar membraneless microchannel fuel cell. J. Power Sources 2005, 139, 96-105. [CrossRef]

52. Déctor, A.; Esquivel, J.P.; González, M.J.; Guerra-Balcázar, M.; Ledesma-García, J.; Sabaté, N.; Arriaga, L.G. Formic acid microfluidic fuel cell evaluation in different oxidant conditions. Electrochim. Acta 2013, 92, 31-35. [CrossRef]

53. Morales-Acosta, D.; Rodríguez, G.H.; Godinez, L.A.; Arriaga, L.G. Performance increase of microfluidic formic acid fuel cell using Pd/MWCNTs as catalyst. J. Power Sources 2010, 195, 1862-1865. [CrossRef]

54. Yoon, S.K.; Fichtl, G.W.; Kenis, P.J.A. Active control of the depletion boundary layers in microfluidic electrochemical reactors. Lab Chip 2006, 6, 1516-1524. [CrossRef]

55. Sprague, I.B.; Dutta, P.; Ha, S. Characterization of a membraneless direct-methanol micro fuel cell. Proc. Inst. Mech. Eng. Part A J. Power Energy 2009, 223, 799-808. [CrossRef]

56. Choban, E.R.; Waszczuk, P.; Kenis, P.J.A. Characterization of limiting factors in laminar flow-based membraneless microfuel cells. Electrochem. Solid State Lett. 2005, 8. [CrossRef]

57. Choban, E.R.; Spendelow, J.S.; Gancs, L.; Wieckowski, A.; Kenis, P.J.A. Membraneless laminar flow-based micro fuel cells operating in alkaline, acidic, and acidic/alkaline media. Electrochim. Acta 2005, 50, 5390-5398. [CrossRef]

58. Galindo, R.; Dector, A.; Arriaga, L.G.; Gutiérrez, S.; Herrasti, P. Maghemite as a catalyst for glucose oxidation in a microfluidic fuel cell. J. Electroanal. Chem. 2012, 671, 38-43. [CrossRef]

59. A Laser-Micromachined Polymeric Membraneless Fuel Cell-IOPscience. Available online: https://iopscience.iop.org/article/ 10.1088/0960-1317/17/6/002 (accessed on 5 April 2020).

60. Sung, W.; Choi, J.W. A membraneless microscale fuel cell using non-noble catalysts in alkaline solution. J. Power Sources 2007, 172, 198-208. [CrossRef]

61. Salloum, K.S.; Posner, J.D. Counter flow membraneless microfluidic fuel cell. J. Power Sources 2010, 195, 6941-6944. [CrossRef]

62. Wang, H.; Gu, S.; Leung, D.Y.C.; Xu, H.; Leung, M.K.H.; Zhang, L.; Xuan, J. Development and characteristics of a membraneless microfluidic fuel cell array. Electrochim. Acta 2014, 135, 467-477. [CrossRef]

63. Xuan, J.; Leung, D.Y.C.; Leung, M.K.H.; Wang, H.; Ni, M. Chaotic flow-based fuel cell built on counter-flow microfluidic network: Predicting the over-limiting current behavior. J. Power Sources 2011, 196, 9391-9397. [CrossRef]

64. Zhang, H.; Xu, H.; Zhang, L.; Leung, D.Y.C.; Wang, H.; Xuan, J. A Counter-flow Microfluidic Fuel Cell Achieving Concentrated Fuel Operation. Energy Procedia 2015, 75, 1990-1995. [CrossRef]

65. Li, L.; Zheng, K.; Ni, M.; Leung, M.K.H.; Xuan, J. Partial modification of flow-through porous electrodes in microfluidic fuel cell. Energy 2015, 88, 563-571. [CrossRef]

66. Tanveer, M.; Kim, K.-Y. Performance analysis of microfluidic fuel cells with various inlet locations and multiple compartments. Energy Convers. Manag. 2018, 166. [CrossRef]

67. Cinti, S.; Minotti, C.; Moscone, D.; Palleschi, G.; Arduini, F. Fully integrated ready-to-use paper-based electrochemical biosensor to detect nerve agents. Biosens. Bioelectron. 2017, 93, 46-51. [CrossRef]

68. Nie, Z.; Nijhuis, C.A.; Gong, J.; Chen, X.; Kumachev, A.; Martinez, A.W.; Narovlyansky, M.; Whitesides, G.M. Electrochemical sensing in paper-based microfluidic devices. Lab Chip 2010, 10, 477-483. [CrossRef] [PubMed] 
69. Zhang, M.; Ge, L.; Ge, S.; Yan, M.; Yu, J.; Huang, J.; Liu, S. Three-dimensional paper-based electrochemiluminescence device for simultaneous detection of $\mathrm{Pb} 2+$ and $\mathrm{Hg} 2+$ based on potential-control technique. Biosens. Bioelectron. 2013, 41, 544-550. [CrossRef] [PubMed]

70. Li, X.; Zhao, C.; Liu, X. A paper-based microfluidic biosensor integrating zinc oxide nanowires for electrochemical glucose detection. Microsyst. Nanoeng. 2015, 1, 1-7. [CrossRef]

71. Liu, H.; Xiang, Y.; Lu, Y.; Crooks, R.M. Aptamer-Based Origami Paper Analytical Device for Electrochemical Detection of Adenosine. Angew. Chem. 2012, 51, 6925-6928. [CrossRef] [PubMed]

72. Zang, D.; Ge, L.; Yan, M.; Song, X.; Yu, J. Electrochemical immunoassay on a 3D microfluidic paper-based device. Chem. Commun. 2012, 48, 4683-4685. [CrossRef]

73. Shen, L.L.; Zhang, G.R.; Li, W.; Biesalski, M.; Etzold, B.J.M. Modifier-Free Microfluidic Electrochemical Sensor for Heavy-Metal Detection. ACS Omega 2017, 2, 4593-4603. [CrossRef]

74. Sun, G.; Wang, P.; Ge, S.; Ge, L.; Yu, J.; Yan, M. Photoelectrochemical sensor for pentachlorophenol on microfluidic paper-based analytical device based on the molecular imprinting technique. Biosens. Bioelectron. 2014, 56, 97-103. [CrossRef]

75. Dossi, N.; Toniolo, R.; Pizzariello, A.; Impellizzieri, F.; Piccin, E.; Bontempelli, G. Pencil-drawn paper supported electrodes as simple electrochemical detectors for paper-based fluidic devices. Electrophoresis 2013, 34, 2085-2091. [CrossRef]

76. Li, Z.; Li, F.; Hu, J.; Wee, W.H.; Han, Y.L.; Pingguan-Murphy, B.; Lu, T.J.; Xu, F. Direct writing electrodes using a ball pen for paper-based point-of-care testing. Analyst 2015, 140, 5526-5535. [CrossRef]

77. Hayes, J.R.; Engstrom, A.M.; Friesen, C. Orthogonal flow membraneless fuel cell. J. Power Sources 2008, 183, 257-259. [CrossRef]

78. Kjeang, E.; McKechnie, J.; Sinton, D.; Djilali, N. Planar and three-dimensional microfluidic fuel cell architectures based on graphite rod electrodes. J. Power Sources 2007, 168, 379-390. [CrossRef]

79. Tominaka, S.; Ohta, S.; Obata, H.; Momma, T.; Osaka, T. On-chip fuel cell: Micro direct methanol fuel cell of an air-breathing, membraneless, and monolithic design. J. Am. Chem. Soc. 2008, 130, 10456-10457. [CrossRef]

80. Wang, L.; Cheng, R.; Wang, W.; Yang, G.; Leung, M.K.H.; Liu, F.; Feng, S.-P. Dual-electrolyte aluminum/air microfluidic fuel cell with electrolyte-recirculation. Electrochim. Acta 2021, 388, 138584. [CrossRef]

81. Zhu, X.; Zhou, Y.; Ye, D.-D.; Chen, R.; Zhang, T.; Liao, Q. Discrete-holes film fueling anode heads for high performance air-breathing microfluidic fuel cell. J. Power Sources 2021, 482, 228966. [CrossRef]

82. Kjeang, E.; Michel, R.; Harrington, D.A.; Djilali, N.; Sinton, D. A microfluidic fuel cell with flow-through porous electrodes. J. Am. Chem. Soc. 2008, 130. [CrossRef]

83. Wang, Y.; Leung, D.Y.C. A high-performance aluminum-feed microfluidic fuel cell stack. J. Power Sources 2016, 336, 427-436. [CrossRef]

84. Kim, S.H.; Kim, K.; Go, M.; Park, J.Y. Stand-alone external power-free microfluidic fuel cell system harnessing osmotic pump for long-term operation. J. Micromech. Microeng. 2018, 28, 125005. [CrossRef]

85. Zhang, Q.; Li, H.; Liu, X.; Zhao, W.; Zong, C.; Gai, H. A self-driven miniaturized liquid fuel cell. Chem. Commun. 2016, 52, 12068-12071. [CrossRef]

86. Hur, J.I.; Meng, D.D.; Kim, C.J. Self-Pumping membraneless miniature fuel cell with an air-breathing cathode. J. Microelectromech. Syst. 2012, 21, 476-483. [CrossRef]

87. Esquivel, J.P.; Del Campo, F.J.; Gómez De La Fuente, J.L.; Rojas, S.; Sabaté, N. Microfluidic fuel cells on paper: Meeting the power needs of next generation lateral flow devices. Energy Environ. Sci. 2014, 7, 1744-1749. [CrossRef]

88. Tanveer, M.; Kim, K.-Y. Effects of bridge-shaped microchannel geometry on the performance of a micro laminar flow fuel cell. Micromachines 2019, 10, 822. [CrossRef] [PubMed]

89. Zhang, B.; Wang, H.N.; Zhu, X.; Ye, D.D.; Liao, Q.; Sui, P.C.; Djilali, N.; Jiang, L.; Fu, Y.L. Effect of geometrical configurations on alkaline air-breathing membraneless microfluidic fuel cells with cylinder anodes. Sci. China Technol. Sci. 2019, 62, 388-396. [CrossRef]

90. Zhu, X.; Zhang, B.; Ye, D.D.; Li, J.; Liao, Q. Air-breathing direct formic acid microfluidic fuel cell with an array of cylinder anodes. J. Power Sources 2014, 247, 346-353. [CrossRef]

91. Ye, D.D.; Zhang, B.; Zhu, X.; Sui, P.C.; Djilali, N.; Liao, Q. Computational modeling of alkaline air-breathing microfluidic fuel cells with an array of cylinder anodes. J. Power Sources 2015, 288, 150-159. [CrossRef]

92. Ha, S.M.; Ahn, Y. Laminar flow-based micro fuel cell utilizing grooved electrode surface. J. Power Sources 2014, 267, 731-738. [CrossRef]

93. Influence of Electrode Groove Geometry on the Passive Control of the Depletion Layer in Microfluidic Fuel Cells-IOPscience. Available online: https:/ /iopscience.iop.org/article/10.1088/0960-1317/25/12/127001 (accessed on 5 April 2020).

94. Ebrahimi Khabbazi, A.; Richards, A.J.; Hoorfar, M. Numerical study of the effect of the channel and electrode geometry on the performance of microfluidic fuel cells. J. Power Sources 2010, 195, 8141-8151. [CrossRef]

95. Thorson, M.R.; Brushett, F.R.; Timberg, C.J.; Kenis, P.J.A. Design rules for electrode arrangement in an air-breathing alkaline direct methanol laminar flow fuel cell. J. Power Sources 2012, 218, 28-33. [CrossRef]

96. Xuan, J.; Leung, D.Y.C.; Leung, M.K.H.; Ni, M.; Wang, H. A computational study of bifunctional oxygen electrode in air-breathing reversible microfluidic fuel cells. Int. J. Hydrogen Energy 2011, 36, 9231-9241. [CrossRef] 
97. Armenta-González, A.J.; Carrera-Cerritos, R.; Moreno-Zuria, A.; Álvarez-Contreras, L.; Ledesma-García, J.; Cuevas-Muñiz, F.M.; Arriaga, L.G. An improved ethanol microfluidic fuel cell based on a PdAg/MWCNT catalyst synthesized by the reverse micelles method. Fuel 2016, 167, 240-247. [CrossRef]

98. Escalona-Villalpando, R.A.; Dector, A.; Dector, D.; Moreno-Zuria, A.; Durón-Torres, S.M.; Galván-Valencia, M.; Arriaga, L.G.; Ledesma-García, J. Glucose microfluidic fuel cell using air as oxidant. Int. J. Hydrogen Energy 2016, 41, 23394-23400. [CrossRef]

99. Shaegh, S.A.M.; Nguyen, N.T.; Chan, S.H. An air-breathing microfluidic formic acid fuel cell with a porous planar anode: Experimental and numerical investigations. J. Micromech. Microeng. 2010, 20. [CrossRef]

100. Ortiz-Ortega, E.; Goulet, M.A.; Lee, J.W.; Guerra-Balcázar, M.; Arjona, N.; Kjeang, E.; Ledesma-García, J.; Arriaga, L.G. A nanofluidic direct formic acid fuel cell with a combined flow-through and air-breathing electrode for high performance. Lab Chip 2014, 14, 4596-4598. [CrossRef]

101. Zhou, Y.; Zhang, B.; Zhu, X.; Ye, D.D.; Chen, R.; Zhang, T.; Gong, X.L.; Liao, Q. Enhancing fuel transport in air-breathing microfluidic fuel cells by immersed fuel micro-jet. J. Power Sources 2020, 445. [CrossRef]

102. Shyu, J.C.; Wang, P.Y.; Lee, C.L.; Chang, S.C.; Sheu, T.S.; Kuo, C.H.; Huang, K.L.; Yang, Z.Y. Fabrication and test of an air-breathing microfluidic fuel cell. Energies 2015, 8, 2082-2096. [CrossRef]

103. Mousavi Shaegh, S.A.; Nguyen, N.T.; Chan, S.H. Air-breathing microfluidic fuel cell with fuel reservoir. J. Power Sources 2012, 209, 312-317. [CrossRef]

104. Zhang, B.; Ye, D.D.; Sui, P.C.; Djilali, N.; Zhu, X. Computational modeling of air-breathing microfluidic fuel cells with flow-over and flow-through anodes. J. Power Sources 2014, 259, 15-24. [CrossRef]

105. Xuan, J.; Leung, D.Y.C.; Wang, H.; Leung, M.K.H.; Wang, B.; Ni, M. Air-breathing membraneless laminar flow-based fuel cells: Do they breathe enough oxygen? Appl. Energy 2013, 104, 400-407. [CrossRef]

106. Jayashree, R.S.; Yoon, S.K.; Brushett, F.R.; Lopez-Montesinos, P.O.; Natarajan, D.; Markoski, L.J.; Kenis, P.J.A. On the performance of membraneless laminar flow-based fuel cells. J. Power Sources 2010, 195, 3569-3578. [CrossRef]

107. Whipple, D.T.; Jayashree, R.S.; Egas, D.; Alonso-Vante, N.; Kenis, P.J.A. Ruthenium cluster-like chalcogenide as a methanol tolerant cathode catalyst in air-breathing laminar flow fuel cells. Electrochim. Acta 2009, 54, 4384-4388. [CrossRef]

108. López-González, B.; Jiménez-Valdés, R.J.; Moreno-Zuria, A.; Cuevas-Muñiz, F.M.; Ledesma-García, J.; García-Cordero, J.L.; Arriaga, L.G. Waste-to-energy conversion from a microfluidic device. J. Power Sources 2017, 360, 80-86. [CrossRef]

109. Jayashree, R.S.; Egas, D.; Spendelow, J.S.; Natarajan, D.; Markoski, L.J.; Kenis, P.J.A. Air-breathing laminar flow-based direct methanol fuel cell with alkaline electrolyte. Electrochem. Solid State Lett. 2006, 9. [CrossRef]

110. Brushett, F.R.; Jayashree, R.S.; Zhou, W.P.; Kenis, P.J.A. Investigation of fuel and media flexible laminar flow-based fuel cells. Electrochim. Acta 2009, 54, 7099-7105. [CrossRef]

111. Chen, C.Y.; Yang, P. Performance of an air-breathing direct methanol fuel cell. J. Power Sources 2003, 123, 37-42. [CrossRef]

112. Goulet, M.A.; Ibrahim, O.A.; Kim, W.H.J.; Kjeang, E. Maximizing the power density of aqueous electrochemical flow cells with in operando deposition. J. Power Sources 2017, 339, 80-85. [CrossRef]

113. Kjeang, E.; Michel, R.; Harrington, D.A.; Sinton, D.; Djilali, N. An alkaline microfluidic fuel cell based on formate and hypochlorite bleach. Electrochim. Acta 2008, 54, 698-705. [CrossRef]

114. Fuerth, D.; Bazylak, A. Up-scaled microfluidic fuel cells with porous flow-through electrodes. J. Fluids Eng. Trans. ASME 2013, 135. [CrossRef]

115. Lee, J.W.; Kjeang, E. Nanofluidic fuel cell. J. Power Sources 2013, 242, 472-477. [CrossRef]

116. Lee, J.W.; Kjeang, E. Chip-embedded thin film current collector for microfluidic fuel cells. Int. J. Hydrogen Energy 2012, 37, 9359-9367. [CrossRef]

117. Mousavi Shaegh, S.A.; Nguyen, N.T.; Mousavi Ehteshami, S.M.; Chan, S.H. A membraneless hydrogen peroxide fuel cell using Prussian Blue as cathode material. Energy Environ. Sci. 2012, 5, 8225-8228. [CrossRef]

118. Mousavi Shaegh, S.A.; Nguyen, N.T.; Chan, S.H.; Zhou, W. Air-breathing membraneless laminar flow-based fuel cell with flow-through anode. Int. J. Hydrogen Energy 2012, 37, 3466-3476. [CrossRef]

119. Moore, S.; Sinton, D.; Erickson, D. A plate-frame flow-through microfluidic fuel cell stack. J. Power Sources 2011, 196, 9481-9487. [CrossRef]

120. Li, L.; Nikiforidis, G.; Leung, M.K.H.; Daoud, W.A. Vanadium microfluidic fuel cell with novel multi-layer flow-through porous electrodes: Model, simulations and experiments. Appl. Energy 2016, 177, 729-739. [CrossRef]

121. Lee, S.H.; Ahn, Y. Upscaling of microfluidic fuel cell using planar single stacks. Int. J. Energy Res. 2019, 43, 5027-5037. [CrossRef]

122. Goulet, M.A.; Kjeang, E. Reactant recirculation in electrochemical co-laminar flow cells. Electrochim. Acta 2014, 140, 217-224. [CrossRef]

123. Lee, J.W.; Goulet, M.A.; Kjeang, E. Microfluidic redox battery. Lab Chip 2013, 13, 2504-2507. [CrossRef]

124. Jayashree, R.S.; Mitchell, M.; Natarajan, D.; Markoski, L.J.; Kenis, P.J.A. Microfluidic hydrogen fuel cell with a liquid electrolyte. Langmuir 2007, 23, 6871-6874. [CrossRef]

125. Lee, S.H.; Ahn, Y. A laminar flow-based single stack of flow-over planar microfluidic fuel cells. J. Power Sources 2017, $351,67-73$. [CrossRef]

126. Ahmed, D.H.; Park, H.B.; Sung, H.J. Optimum geometrical design for improved fuel utilization in membraneless micro fuel cell. J. Power Sources 2008, 185, 143-152. [CrossRef] 
127. Wu, R.; Ye, D.; Chen, R.; Zhang, B.; Zhu, X.; Guo, H.; Liu, Z. A membraneless microfluidic fuel cell with continuous multistream flow through cotton threads. Int. J. Energy Res. 2020, 44, 2243-2251. [CrossRef]

128. Kwok, Y.H.; Wang, Y.; Wu, M.; Li, F.; Zhang, Y.; Zhang, H.; Leung, D.Y.C. A dual fuel microfluidic fuel cell utilizing solar energy and methanol. J. Power Sources 2019, 409, 58-65. [CrossRef]

129. Lu, X.; Xuan, J.; Leung, D.Y.C.; Zou, H.; Li, J.; Wang, H.; Wang, H. A switchable pH-differential unitized regenerative fuel cell with high performance. J. Power Sources 2016, 314, 76-84. [CrossRef]

130. Ibrahim, O.A.; Goulet, M.A.; Kjeang, E. In-situ characterization of symmetric dual-pass architecture of microfluidic co-laminar flow cells. Electrochim. Acta 2016, 187, 277-285. [CrossRef]

131. Ibrahim, O.A.; Kjeang, E. Leveraging co-laminar flow cells for non-aqueous electrochemical systems. J. Power Sources 2018, 402, 7-14. [CrossRef]

132. Ho, B.; Kjeang, E. Planar multiplexing of microfluidic fuel cells. J. Fluids Eng. Trans. ASME 2013, 135. [CrossRef]

133. An, L.; Zhao, T.; Yan, X.; Zhou, X.; Tan, P. The dual role of hydrogen peroxide in fuel cells. Sci. Bull. 2015, 60, 55-64. [CrossRef]

134. Togo, M.; Takamura, A.; Asai, T.; Kaji, H.; Nishizawa, M. An enzyme-based microfluidic biofuel cell using vitamin K3-mediated glucose oxidation. Electrochim. Acta 2007, 52, 4669-4674. [CrossRef]

135. Togo, M.; Takamura, A.; Asai, T.; Kaji, H.; Nishizawa, M. Structural studies of enzyme-based microfluidic biofuel cells. J. Power Sources 2008, 178, 53-58. [CrossRef]

136. Arun, R.K.; Sardar, M.; Singh, P.; Jha, B.M.; Chanda, N. A spiral shaped regenerative microfluidic fuel cell with Ni-C based porous electrodes. Int. J. Energy Res. 2019, 43, 8834-8840. [CrossRef]

137. Lu, X.; Wang, Y.; Leung, D.Y.C.; Xuan, J.; Wang, H. A counter-flow-based dual-electrolyte protocol for multiple electrochemical applications. Appl. Energy 2018, 217, 241-248. [CrossRef]

138. Lu, X.; Leung, D.Y.C.; Wang, Y.; Wang, H.; Xuan, J. An Up-scaling Strategy for Counter-flow Based Microfluidic Network: A Numerical Study. Energy Procedia 2017, 142, 661-666. [CrossRef]

139. Wang, H.; Leung, D.Y.C.; Xuan, J. Modeling of an air cathode for microfluidic fuel cells: Transport and polarization behaviors. Int. J. Hydrogen Energy 2011, 36, 14704-14718. [CrossRef]

140. Xu, H.; Zhang, H.; Wang, H.; Leung, D.Y.C.; Zhang, L.; Cao, J.; Jiao, K.; Xuan, J. Counter-flow formic acid microfluidic fuel cell with high fuel utilization exceeding 90\%. Appl. Energy 2015, 160, 930-936. [CrossRef]

141. Wang, Y.; Leung, D.Y.C.; Zhang, H.; Xuan, J.; Wang, H. Numerical and experimental comparative study of microfluidic fuel cells with different flow configurations: Co-flow vs. counter-flow cell. Appl. Energy 2017, 203, 535-548. [CrossRef]

142. Wang, Y.; Leung, D.Y.C. Toward the scaling up of microfluidic fuel cells, investigation and optimization of the aggravated cathode flooding problem. Electrochim. Acta 2016, 222, 312-322. [CrossRef]

143. Tanveer, M.; Kim, K.-Y. Performance analysis of a micro laminar flow fuel cell with multiple inlets of a bridge-shaped microchannel. J. Power Sources 2018, 399. [CrossRef]

144. Li, L.; Bei, S.; Liu, R.; Xu, Q.; Zheng, K.; She, Y.; He, Y. Design of a radial vanadium redox microfluidic fuel cell: A new way to break the size limitation. Int. J. Energy Res. 2019, 43, 3028-3037. [CrossRef]

145. Osborn, J.L.; Lutz, B.; Fu, E.; Kauffman, P.; Stevens, D.Y.; Yager, P. Microfluidics without pumps: Reinventing the T-sensor and H-filter in paper networks. Lab Chip 2010, 10, 2659-2665. [CrossRef]

146. Tata Rao, L.; Rewatkar, P.; Dubey, S.K.; Javed, A.; Goel, S. Performance optimization of microfluidic paper fuel-cell with varying cellulose fiber papers as absorbent pad. Int. J. Energy Res. 2020, 44, 3893-3904. [CrossRef]

147. Arun, R.K.; Gupta, V.; Singh, P.; Biswas, G.; Chanda, N. Selection of Graphite Pencil Grades for the Design of Suitable Electrodes for Stacking Multiple Single-Inlet Paper-Pencil Fuel Cells. ChemistrySelect 2019, 4, 152-159. [CrossRef]

148. Yan, X.; Xu, A.; Zeng, L.; Gao, P.; Zhao, T. A Paper-Based Microfluidic Fuel Cell with Hydrogen Peroxide as Fuel and Oxidant. Energy Technol. 2018, 6, 140-143. [CrossRef]

149. del Torno-de Román, L.; Navarro, M.; Hughes, G.; Esquivel, J.P.; Milton, R.D.; Minteer, S.D.; Sabaté, N. Improved performance of a paper-based glucose fuel cell by capillary induced flow. Electrochim. Acta 2018, 282, 336-342. [CrossRef]

150. Shen, L.L.; Zhang, G.R.; Venter, T.; Biesalski, M.; Etzold, B.J.M. Towards best practices for improving paper-based microfluidic fuel cells. Electrochim. Acta 2019, 298, 389-399. [CrossRef]

151. Jung, D.G.; Ahn, Y. Microfabricated paper-based vanadium co-laminar flow fuel cell. J. Power Sources 2020, 451. [CrossRef]

152. Pasala, V.; Ramanujam, K. Flexible paper-based borohydride-vanadium fuel cell for powering micro-nanosystems. Ionics 2017, 23, 1811-1817. [CrossRef]

153. Chino, I.; Muneeb, O.; Do, E.; Ho, V.; Haan, J.L. A paper microfluidic fuel cell powered by urea. J. Power Sources 2018, 396, 710-714. [CrossRef]

154. Galvan, V.; Domalaon, K.; Tang, C.; Sotez, S.; Mendez, A.; Jalali-Heravi, M.; Purohit, K.; Pham, L.; Haan, J.; Gomez, F.A. An improved alkaline direct formate paper microfluidic fuel cell. Electrophoresis 2016, 37, 504-510. [CrossRef]

155. Esquivel, J.P.; Buser, J.R.; Lim, C.W.; Domínguez, C.; Rojas, S.; Yager, P.; Sabaté, N. Single-use paper-based hydrogen fuel cells for point-of-care diagnostic applications. J. Power Sources 2017, 342, 442-451. [CrossRef]

156. Chandra, S.; Lal, S.; Janardhanan, V.M.; Sahu, K.C.; Deepa, M. Ethanol based fuel cell on paper support. J. Power Sources 2018, 396, 725-733. [CrossRef]

157. Lal, S.; Deepa, M.; Janardhanan, V.M.; Sahu, K.C. Paper based hydrazine monohydrate fuel cells with Cu and C composite catalysts. Electrochim. Acta 2017, 232, 262-270. [CrossRef] 
158. Lal, S.; Janardhanan, V.M.; Deepa, M.; Sagar, A.; Sahu, K.C. Low Cost Environmentally Benign Porous Paper Based Fuel Cells for Micro-Nano Systems. J. Electrochem. Soc. 2015, 162, F1402-F1407. [CrossRef]

159. González-Guerrero, M.J.; del Campo, F.J.; Esquivel, J.P.; Giroud, F.; Minteer, S.D.; Sabaté, N. Paper-based enzymatic microfluidic fuel cell: From a two-stream flow device to a single-stream lateral flow strip. J. Power Sources 2016, 326, 410-416. [CrossRef]

160. Purohit, K.H.; Emrani, S.; Rodriguez, S.; Liaw, S.S.; Pham, L.; Galvan, V.; Domalaon, K.; Gomez, F.A.; Haan, J.L. A microfluidic galvanic cell on a single layer of paper. J. Power Sources 2016, 318, 163-169. [CrossRef]

161. Arun, R.K.; Halder, S.; Chanda, N.; Chakraborty, S. A paper based self-pumping and self-breathing fuel cell using pencil stroked graphite electrodes. Lab Chip 2014, 14, 1661-1664. [CrossRef]

162. Copenhaver, T.S.; Purohit, K.H.; Domalaon, K.; Pham, L.; Burgess, B.J.; Manorothkul, N.; Galvan, V.; Sotez, S.; Gomez, F.A.; Haan, J.L. A microfluidic direct formate fuel cell on paper. Electrophoresis 2015, 36, 1825-1829. [CrossRef]

163. Mousavi Ehteshami, S.M.; Asadnia, M.; Tan, S.N.; Chan, S.H. Paper-based membraneless hydrogen peroxide fuel cell prepared by micro-fabrication. J. Power Sources 2016, 301, 392-395. [CrossRef]

164. Wang, Y.; Kwok, H.Y.H.; Zhang, Y.; Pan, W.; Zhang, H.; Lu, X.; Leung, D.Y.C. A flexible paper-based hydrogen fuel cell for small power applications. Int. J. Hydrogen Energy 2019, 44, 29680-29691. [CrossRef]

165. Dector, A.; Galindo-de-la-Rosa, J.; Amaya-Cruz, D.M.; Ortíz-Verdín, A.; Guerra-Balcázar, M.; Olivares-Ramírez, J.M.; Arriaga, L.G.; Ledesma-García, J. Towards autonomous lateral flow assays: Paper-based microfluidic fuel cell inside an HIV-test using a blood sample as fuel. Int. J. Hydrogen Energy 2017, 42, 27979-27986. [CrossRef]

166. Domalaon, K.; Tang, C.; Mendez, A.; Bernal, F.; Purohit, K.; Pham, L.; Haan, J.; Gomez, F.A. Fabric-based alkaline direct formate microfluidic fuel cells. Electrophoresis 2017, 38, 1224-1231. [CrossRef]

167. Liu, Z.; Ye, D.; Chen, R.; Zhang, B.; Zhu, X.; Li, J.; Liao, Q. A woven thread-based microfluidic fuel cell with graphite rod electrodes. Int. J. Hydrogen Energy 2018, 43, 22467-22473. [CrossRef]

168. Pasala, V.; Ramanujam, K. Paper-Based Disposable Zinc-Vanadium Fuel Cell for Micropower Applications. ChemistrySelect 2019, 4, 8398-8403. [CrossRef]

169. Salloum, K.S.; Posner, J.D. A membraneless microfluidic fuel cell stack. J. Power Sources 2011, 196, 1229-1234. [CrossRef]

170. Abrego-Martínez, J.C.; Moreno-Zuria, A.; Cuevas-Muñiz, F.M.; Arriaga, L.G.; Sun, S.; Mohamedi, M. Design, fabrication and performance of a mixed-reactant membraneless micro direct methanol fuel cell stack. J. Power Sources 2017, 371, 10-17. [CrossRef]

171. Moreno-Zuria, A.; Ortiz-Ortega, E.; Gurrola, M.P.; Chávez-Ramírez, A.U.; Ledesma-García, J.; Arriaga, L.G. Evolution of microfluidic fuel stack design as an innovative alternative to energy production. Int. J. Hydrogen Energy 2017, 42, 27929-27939. [CrossRef]

172. Wang, Y.; Leung, D.Y.C.; Xuan, J.; Wang, H. A review on unitized regenerative fuel cell technologies, part B: Unitized regenerative alkaline fuel cell, solid oxide fuel cell, and microfluidic fuel cell. Renew. Sustain. Energy Rev. 2017, 75, 775-795. [CrossRef]

173. Bamgbopa, M.O.; Almheiri, S.; Sun, H. Prospects of recently developed membraneless cell designs for redox flow batteries. Renew. Sustain. Energy Rev. 2017, 70, 506-518. [CrossRef]

174. Wang, Y.; Leung, D.Y.C. A circular stacking strategy for microfluidic fuel cells with volatile methanol fuel. Appl. Energy 2016, 184, 659-669. [CrossRef]

175. Ibrahim, O.A.; Goulet, M.-A.; Kjeang, E. Microfluidic Electrochemical Cell Array in Series: Effect of Shunt Current. J. Electrochem. Soc. 2015, 162, F639-F644. [CrossRef]

176. Galindo-de-la-Rosa, J.; Arjona, N.; Moreno-Zuria, A.; Ortiz-Ortega, E.; Guerra-Balcázar, M.; Ledesma-García, J.; Arriaga, L.G. Evaluation of single and stack membraneless enzymatic fuel cells based on ethanol in simulated body fluids. Biosens. Bioelectron. 2017, 92, 117-124. [CrossRef] [PubMed]

177. Escalona-Villalpando, R.A.; Hasan, K.; Milton, R.D.; Moreno-Zuria, A.; Arriaga, L.G.; Minteer, S.D.; Ledesma-García, J. Performance comparison of different configurations of Glucose/O2 microfluidic biofuel cell stack. J. Power Sources 2019, 414, 150-157. [CrossRef]

178. Yang, W.; Lee, K.K.; Choi, S. A laminar-flow based microbial fuel cell array. Sens. Actuators B Chem. 2017, 243, 292-297. [CrossRef]

179. Brushett, F.R.; Zhou, W.P.; Jayashree, R.S.; Kenis, P.J. Alkaline Microfluidic Hydrogen-Oxygen Fuel Cell as a Cathode Characterization Platform. J. Electrochem. Soc. 2009, 156, B565-B571. [CrossRef]

180. Hollinger, A.S.; Maloney, R.J.; Jayashree, R.S.; Natarajan, D.; Markoski, L.J.; Kenis, P.J.A. Nanoporous separator and low fuel concentration to minimize crossover in direct methanol laminar flow fuel cells. J. Power Sources 2010, 195, 3523-3528. [CrossRef]

181. Wang, Y.; Leung, D.Y.C.; Xuan, J.; Wang, H. A vapor feed methanol microfluidic fuel cell with high fuel and energy efficiency. Appl. Energy 2015, 147, 456-465. [CrossRef]

182. Brushett, F.; Mitchell, M.; Jayashree, R.; Zhou, W.-P.; Kenis, P. Vapor Feed Direct Methanol Fuel Cell with Flowing Electrolyte. ECS Trans. 2007, 11, 1419-1424. [CrossRef]

183. Yang, Y.; Xue, Y.; Huang, F.; Zhang, H.; Tao, K.; Zhang, R.; Shen, Q.; Chang, H. A Facile Microfluidic Hydrogen Peroxide Fuel Cell with High Performance: Electrode Interface and Power-Generation Properties. ACS Appl. Energy Mater. $2018,1,5328-5335$. [CrossRef]

184. Shyu, J.C.; Huang, C.L.; Sheu, T.S.; Ay, H. Experimental study of direct hydrogen peroxide microfluidic fuel cells. Micro Nano Lett. 2012, 7, 740-743. [CrossRef] 
185. Chen, F.; Chang, M.H.; Hsu, C.W. Analysis of membraneless microfuel cell using decomposition of hydrogen peroxide in a Y-shaped microchannel. Electrochim. Acta 2007, 52, 7270-7277. [CrossRef]

186. Ye, D.; Yang, Y.; Li, J.; Zhu, X.; Liao, Q.; Zhang, B. A laminar flow microfluidic fuel cell for detection of hexavalent chromium concentration. Biomicrofluidics 2015, 9, 064110. [CrossRef]

187. Moore, C.M.; Minteer, S.B.; Martin, R.S. Microchip-based ethanol/oxygen biofuel cell. Lab Chip 2005, 5, 218-225. [CrossRef] [PubMed]

188. Da Mota, N.; Finkelstein, D.A.; Kirtland, J.D.; Rodriguez, C.A.; Stroock, A.D.; Abruña, H.D. Membraneless, room-temperature, direct borohydride/cerium fuel cell with power density of over $0.25 \mathrm{~W} / \mathrm{cm}^{2}$. J. Am. Chem. Soc. 2012, 134, 6076-6079. [CrossRef] [PubMed]

189. Arjona, N.; Palacios, A.; Moreno Zuria, A.; Guerra-Balcázar, M.; Ledesma García, J.; Arriaga, L.G. AuPd/polyaniline as the anode in an ethylene glycol microfluidic fuel cell operated at room temperature. Chem. Commun. 2014, 50, 8151-8153. [CrossRef] [PubMed]

190. Dector, A.; Cuevas-Muñiz, F.M.; Guerra-Balcázar, M.; Godínez, L.A.; Ledesma-García, J.; Arriaga, L.G. Glycerol oxidation in a microfluidic fuel cell using Pd/C and Pd/MWCNT anodes electrodes. Int. J. Hydrogen Energy 2013, 38, 12617-12622. [CrossRef]

191. Zhang, H.; Wang, Y.; Wu, Z.; Leung, D.Y.C. A direct urea microfluidic fuel cell with flow-through Ni-supported-carbon-nanotubecoated sponge as porous electrode. J. Power Sources 2017, 363, 61-69. [CrossRef]

192. Zhang, H.M.; Wang, Y.F.; Kwok, Y.H.; Wu, Z.C.; Xia, D.H.; Leung, D.Y.C. A Direct Ammonia Microfluidic Fuel Cell using NiCu Nanoparticles Supported on Carbon Nanotubes as an Electrocatalyst. ChemSusChem 2018, 11, 2889-2897. [CrossRef]

193. Braff, W.A.; Bazant, M.Z.; Buie, C.R. Membrane-less hydrogen bromine flow battery. Nat. Commun. 2013, 4, 1-6. [CrossRef]

194. Martins, C.A.; Ibrahim, O.A.; Pei, P.; Kjeang, E. "Bleaching" glycerol in a microfluidic fuel cell to produce high power density at minimal cost. Chem. Commun. 2017, 54, 192-195. [CrossRef]

195. Martins, C.A.; Ibrahim, O.A.; Pei, P.; Kjeang, E. Towards a fuel-flexible direct alcohol microfluidic fuel cell with flow-through porous electrodes: Assessment of methanol, ethylene glycol and glycerol fuels. Electrochim. Acta 2018, 271, 537-543. [CrossRef]

196. Yu, X.; Cheng, L.; Liu, Y.; Manthiram, A. A Membraneless Direct Isopropanol Fuel Cell (DIPAFC) Operated with a CatalystSelective Principle. J. Phys. Chem. C 2018, 122, 13558-13563. [CrossRef]

197. Maya-Cornejo, J.; Ortiz-Ortega, E.; Álvarez-Contreras, L.; Arjona, N.; Guerra-Balcázar, M.; Ledesma-García, J.; Arriaga, L.G. Copper-palladium core-shell as an anode in a multi-fuel membraneless nanofluidic fuel cell: Toward a new era of small energy conversion devices. Chem. Commun. 2015, 51, 2536-2539. [CrossRef] [PubMed]

198. Kwok, Y.H.; Tsang, A.C.H.; Wang, Y.; Leung, D.Y.C. Ultra-fine Pt nanoparticles on graphene aerogel as a porous electrode with high stability for microfluidic methanol fuel cell. J. Power Sources 2017, 349, 75-83. [CrossRef]

199. Kwok, Y.H.; Wang, Y.F.; Tsang, A.C.H.; Leung, D.Y.C. Graphene-carbon nanotube composite aerogel with Ru@Pt nanoparticle as a porous electrode for direct methanol microfluidic fuel cell. Appl. Energy 2018, 217, 258-265. [CrossRef]

200. Guo, S.; Sun, J.; Zhang, Z.; Sheng, A.; Gao, M.; Wang, Z.; Zhao, B.; Ding, W. Study of the electrooxidation of borohydride on a directly formed $\mathrm{CoB} / \mathrm{Ni}$-foam electrode and its application in membraneless direct borohydride fuel cells. J. Mater. Chem. A 2017, 5, 15879-15890. [CrossRef]

201. Zhong, H.; Tian, R.; Gong, X.; Li, D.; Tang, P.; Alonso-Vante, N.; Feng, Y. Advanced bifunctional electrocatalyst generated through cobalt phthalocyanine tetrasulfonate intercalated $\mathrm{Ni}_{2} \mathrm{Fe}$-layered double hydroxides for a laminar flow unitized regenerative micro-cell. J. Power Sources 2017, 361, 21-30. [CrossRef]

202. Lee, J.; Keng, G.L.; Palmore, G.T.R.; Tripathi, A. Optimization of microfluidic fuel cells using transport principles. Anal. Chem. 2007, 79, 7301-7307. [CrossRef] [PubMed]

203. Liu, Z.; Ye, D.; Chen, R.; Zhang, B.; Zhu, X.; Liao, Q. A dual-functional three-dimensional herringbone-like electrode for a membraneless microfluidic fuel cell. J. Power Sources 2019, 438, 227058. [CrossRef]

204. López-González, B.; Dector, A.; Cuevas-Muñiz, F.M.; Arjona, N.; Cruz-Madrid, C.; Arana-Cuenca, A.; Guerra-Balcázar, M.; Arriaga, L.G.; Ledesma-García, J. Hybrid microfluidic fuel cell based on Laccase/C and AuAg/C electrodes. Biosens. Bioelectron. 2014, 62, 221-226. [CrossRef]

205. Ye, D.; Yang, Y.; Li, J.; Zhu, X.; Liao, Q.; Deng, B.; Chen, R. Performance of a microfluidic microbial fuel cell based on graphite electrodes. Int. J. Hydrogen Energy 2013, 38, 15710-15715. [CrossRef]

206. Brushett, F.R.; Duong, H.T.; Ng, D.; Behrens, R.L.; Wieckowski, A.; Kenis, P.J.A. Investigation of Pt, $\mathrm{Pt}{ }_{3} \mathrm{Co}, \mathrm{and} \mathrm{Pt}_{3} \mathrm{Co} / \mathrm{Mo}$ Cathodes for the ORR in a Microfluidic $\mathrm{H}_{2} / \mathrm{O}_{2}$ Fuel Cell. J. Electrochem. Soc. 2010, 157, B837. [CrossRef]

207. Park, H.B.; Lee, K.H.; Sung, H.J. Performance of H-shaped membraneless micro fuel cells. J. Power Sources 2013, $226,266-271$. [CrossRef]

208. Xu, Q.; She, Y.; Li, L. Model-based analysis of geometrical effects in microfluidic fuel cell with flow-through porous electrodes. Int. J. Mod. Phys. B 2019. [CrossRef]

209. Marschewski, J.; Ruch, P.; Ebejer, N.; Huerta Kanan, O.; Lhermitte, G.; Cabrol, Q.; Michel, B.; Poulikakos, D. On the mass transfer performance enhancement of membraneless redox flow cells with mixing promoters. Int. J. Heat Mass Transf. 2017, 106, 884-894. [CrossRef]

210. Miao, S.; He, S.; Liang, M.; Lin, G.; Cai, B.; Schmidt, O.G. Microtubular Fuel Cell with Ultrahigh Power Output per Footprint. Adv. Mater. 2017, 29, 1607046. [CrossRef] 
211. Yeh, E.C.; Fu, C.C.; Hu, L.; Thakur, R.; Feng, J.; Lee, L.P. Self-powered integrated microfluidic point-of-care low-cost enabling (SIMPLE) chip. Sci. Adv. 2017, 3, e1501645. [CrossRef]

212. Gurrola, M.P.; Ortiz-Ortega, E.; Farias-Zuñiga, C.; Chávez-Ramírez, A.U.; Ledesma-García, J.; Arriaga, L.G. Evaluation and coupling of a membraneless nanofluidic device for low-power applications. J. Power Sources 2016, 307, 244-250. [CrossRef] 